\title{
Vitrimers: Permanently crosslinked polymers with dynamic
}

\section{network topology}

\author{
Nathan J. Van Zee* and Renaud Nicolä̈*
}

Chimie Moléculaire, Macromoléculaire, Matériaux, ESPCI Paris, CNRS, Université PSL, 10 rue Vauquelin, 75005 Paris, France

*Corresponding authors. E-mail addresses: nathan.van-zee@espci.fr, renaud.nicolay@espci.fr.

\begin{abstract}
The study of synthetic organic polymers rapidly expanded since Staudinger's recognition of the covalent structure of macromolecules. Today, these materials are far from just an academic concept - they are produced industrially and have become ubiquitous in everyday life because of their low cost and desirable physical properties. Nevertheless, a difficult choice between durability and reprocessability continues to hamper efforts to design synthetic organic polymers to be more recyclable. A new class of materials, vitrimers, has emerged as an intriguing approach to circumvent this tradeoff. Vitrimers are permanent networks of polymer chains connected via dynamic covalent bonds, which allow the network to change its topology while maintaining a constant number of chemical bonds at all temperatures. Characterized by both high mechanical performance and facile processing, vitrimers are well positioned to transition from academic labs to industrial production. The aim of this Trend article is to review the concept of vitrimers, describe their most unique properties, and present our outlook on outstanding challenges that must be met to realize vitrimers as a next generation solution for recyclable high performance materials.
\end{abstract}




\section{Table of Contents}

1. Introduction

2. Vitrimers: Vitrimers: Definitions and key properties

2.1. Definition of dynamic covalent bonds in the context of vitrimers

2.2. Thermally triggered solid-to-viscoelastic-liquid transition: $T_{\mathrm{v}}$ and viscoelastic properties

2.3. Adhesion

2.4. Recyclability

3. Vitrimers: Chemistry

3.1. Synthetic strategies to prepare vitrimers

3.2. Exchangeable chemical bonds

4. Vitrimers: present and future

4.1. New chemistries and synthetic routes

4.2. Solubility

4.3. Flow properties

4.4. Advanced vitrimers

5. Conclusion 


\begin{abstract}
Abbreviations
$T_{\mathrm{g}}$, glass transition temperature; $T_{\mathrm{m}}$, melting transition temperature; $K$, thermodynamic equilibrium constant; $k$, rate constant; WLF model, Williams, Landel, and Ferry model; $T_{\mathrm{v}}$, topology freezing temperature; TBD, 1,5,7-triazabicyclo[4.4.0]dec-5-ene; HDPE, high density polyethylene; PMMA, poly(methyl methacrylate); CNT, carbon nanotubes; THF, tetrahydrofuran; DMA, dynamic mechanical analysis
\end{abstract}




\section{Introduction}

Since the seminal work of Hermann Staudinger, who first postulated the covalent structure of polymers, $[1,2]$ advances in polymer chemistry and physics have led to new fields and concepts with applications covering essentially all industrial sectors. The omnipresence of synthetic organic polymers in everyday life stems from their low cost and light weight, as well as their wide range of properties. Over the last century, chemists have developed numerous tools that allow for precise control over the size and dispersity of synthetic polymers, as well as their composition, functionality and topology, which in turn dictate their chemical, physicochemical and mechanical properties.[3-10]

A common classification of polymers is based on how they respond to heat, which is directly linked to the topology of the polymer chains. The first family is thermoplastics, which macroscopically flow like viscoelastic liquids when heated above the glass transition temperature, $T_{\mathrm{g}}$ (or the melting temperature, $T_{\mathrm{m}}$, in the case of semi-crystalline polymers).[11-13] They are constituted of polymer chains that are not chemically connected to each other but have a sufficient molecular weight to be entangled. Their molecular mobility in the molten state permits them to be repeatedly melted and molded.[14] However, thermoplastics are not suited for applications requiring rubbery solids, dimensional stability at high temperature, or superior environmental stress cracking resistance.

To address these limitations, polymer chains can be covalently crosslinked to form thermosets, the second category of polymeric materials. The formation of the threedimensional network suppresses polymer chain diffusion under the action of heat or a solvent, making thermosets inherently insoluble. Above the $T_{\mathrm{g}}$, thermosets present a theoretically infinite rubbery plateau because they cannot flow and exhibit an elastic modulus that is a function of the crosslinking density. These characteristics enable thermosets to be useful for applications requiring creep resistance, solvent resistance, or high mechanical 
strength, such as structural applications, coatings, adhesives, electronics and composites.[15] However, the topology of the network and the macroscopic shape of thermosets are "set" once they are cured, preventing them from being processed multiple times.[15, 16]

Difficult tradeoffs with respect to processability, durability, and recyclability thus beset the choice between using a thermoplastic or a thermoset for a given application. Motivated by both the intellectual challenge and societal demand for recyclable high performance materials, scientists have sought to marry the malleability of thermoplastics with the performance advantages of thermosets. The prevailing strategy is to create a network of polymer chains in which the crosslinks can be broken and reformed within a desired temperature window and using a triggered stimulus. The earliest examples are nanostructured thermoplastic elastomers that rely on phase separation to physically crosslink polymers chains, $[17,18]$ as well as polymers that feature polar or hydrogen-bonding groups in the main chain (e.g., nylon).

This approach has been broadly expanded to supramolecular networks[19-21] containing non-covalent transient crosslinks that operate through hydrogen bonds, [22] $\pi-\pi$ interactions[23] and metal complexation.[24] These interactions are described by a thermodynamic equilibrium constant $K$, which dictates the equilibrium between the associated and the dissociated forms and therefore the connectivity of the system. Such systems are also characterized by rate constants for the bond formation and rupture of the transient links, which relates to the dynamicity of the system. The thermodynamic and kinetic constants are temperature dependent and both greatly impact the viscoelastic properties of reversible networks. Supramolecularly crosslinked materials tend to have $K$ values that strongly decrease with temperature as well as high rates of exchange, which are not ideal for applications that demand creep resistance. 

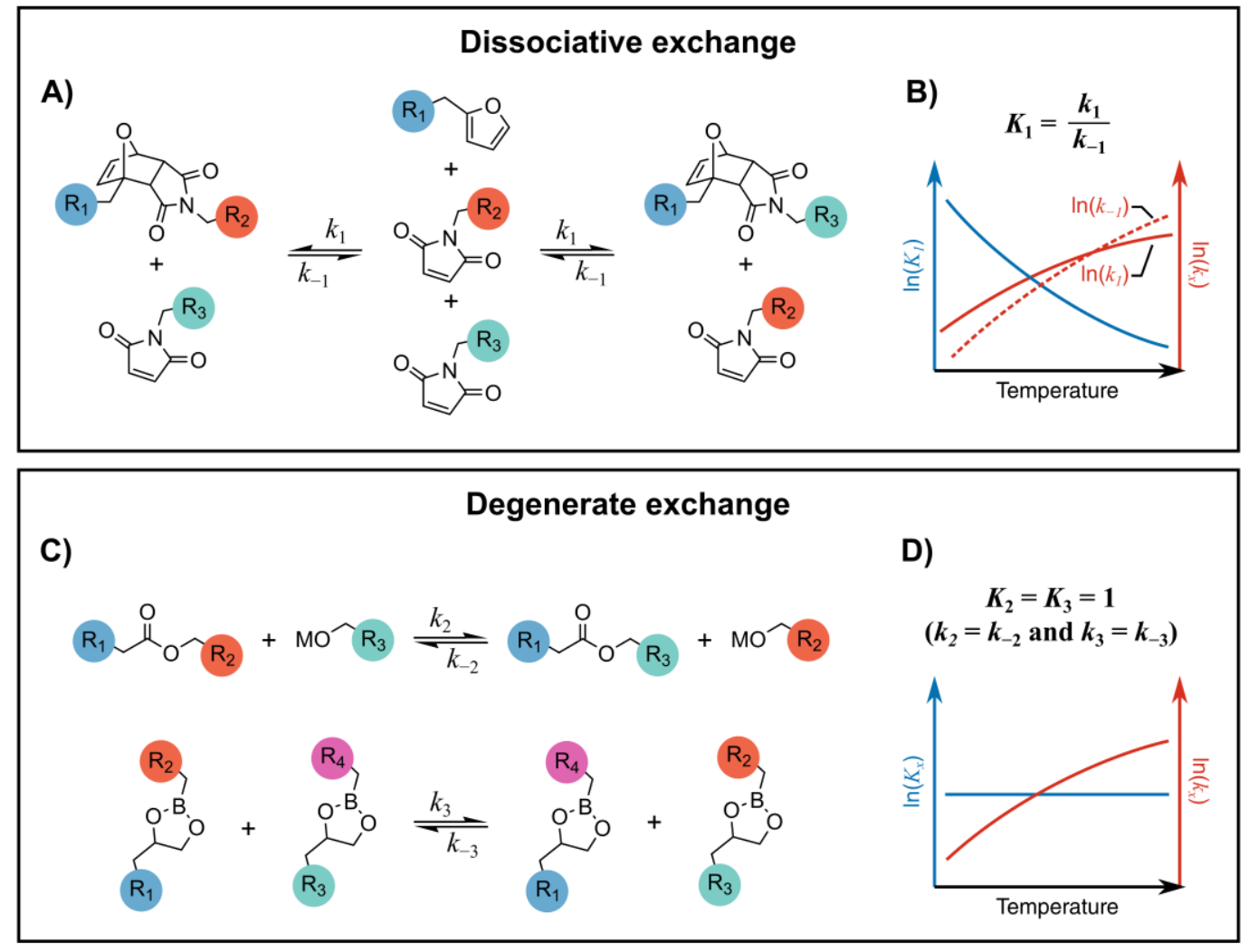

Figure 1. A) Dissociative exchange exemplified with consecutive Diels-Alder adduct dissociation and cycloaddition in the presence of a free maleimide. B) Qualitative plot of $\ln \left(K_{1}\right)$ (solid blue line), $\ln \left(k_{1}\right)$ (solid red line), and $\ln \left(k_{-1}\right)$ (dashed red line) versus temperature for the dissociative exchange between Diels-Alder adducts. C) Degenerate exchange exemplified with the transesterification of an ester with an activated alcohol (top, $M=$ metal catalyst) and the metathesis of boronic esters (bottom). D) Qualitative plot of $\ln \left(K_{\mathrm{x}}\right)$ (solid blue line) and $\ln \left(k_{\mathrm{x}}\right)$ (solid red line) versus temperature that applies to both the degenerate exchange of ester transesterification and boronic ester metathesis.

Polymer networks that are crosslinked via reversible covalent bonds are conceptually similar to non-covalently crosslinked networks, but they are distinguished by the strength and life-time of the covalent interaction. Depending on the nature of the reversible covalent bond, various stimuli can be used to push the equilibrium between the associated and dissociated states. For example, reversible covalent networks have been prepared using thermally 
activated groups (e.g., Diels-Alder adducts,[25, 26] alkoxyamines,[27] urethanes and urea,[28, 29] triazolinediones,[30] 1,2,3-triazoliums,[31] and aniliniums,[32]); photoactivated groups (e.g., coumarin dimers,[33-35] trithiocarbonates,[36] disulfides,[37] and diarylbibenzofuranone derivatives[38]) and chemically activated groups (e.g., boronic esters, [39, 40] disulfides,[41, 42] acylhydrazones, [43, 44] imines,[41, 45] and acetals[46]). The observed modulation of macroscopic properties is primarily driven by a change in the degree of crosslinking, which is dictated by the equilibrium constant of the reversible covalent crosslinking group (Fig. 1A). At high temperatures, the rate of the dissociation reaction becomes faster than the rate of the association reaction (Fig. 1B). These materials thus experience a loss of network integrity in the dissociated state, which is disadvantageous in applications that demand facile shaping and welding.

Recently, a conceptually unique approach to polymer networks was introduced that combine the temperature-independent and permanent structure of thermosets with the malleability and reprocessability of thermoplastics. These new polymer materials are called vitrimers and were introduced by Leibler and co-workers in 2011.[47-49] Vitrimers feature dynamic covalent crosslinks that do not dissociate in the course of the exchange reaction. However, despite a constant degree of crosslinking, these materials can flow under the action of heat depending on the kinetics of the exchange reaction. Vitrimers are able to achieve a compelling balance of robust mechanical properties and processability. We believe that this approach will be key to realizing recyclable high performance materials in the future. The aim of this Trend article is to describe the most important fundamental aspects of vitrimers, present the synthetic routes to access these materials, and finally discuss the challenges that we believe must be addressed to transition vitrimers from an academic concept to commercial products. 


\section{Vitrimers: Definitions and key properties}

\subsection{Definition of dynamic covalent bonds in the context of vitrimers}

Vitrimers are permanent chemical networks with dynamic covalent bonds that allow the network to change its topology while maintaining a constant number of chemical bonds in the system at all temperatures below degradation. The term "dynamic" is defined with deference to Lehn's pioneering work on dynamers.[50] Dynamic covalent bonds are reversible and can rapidly reach thermodynamic equilibrium in response to a stimulus. In the context of vitrimers, the topological rearrangement of the network operates through thermally activated degenerate reactions between dynamic covalent units, allowing these systems to fully relax external stresses.

In a degenerate process, the chemical entities are identical on both sides of the equilibrium (Fig. 1B) and the thermodynamic equilibrium constant is by definition 1 at any temperature; that is, the forward and reverse exchange reaction rates are equal to each other at all temperatures (Fig. 1C). This characteristic provides vitrimers with a constant number of chemical bonds regardless of the temperature. On the other hand, the lifetime of the dynamic bonds, and therefore the flow properties of vitrimers, are temperature-dependent. Vitrimers can thus undergo a thermally triggered and reversible transition from a (visco)elastic solid to a viscoelastic liquid while preserving a constant number of crosslinks. This characteristic distinguishes vitrimers from dynamic networks that experience a decrease of their connectivity with increased temperature (Fig. 1B) and provides vitrimers with different thermomechanical and flow properties.[51-53] 


\subsection{Thermally triggered solid-to-viscoelastic-liquid transition: $T_{\mathrm{v}}$ and viscoelastic properties}

Thermosets behave as glassy solids at temperatures below their $T_{\mathrm{g}}$ and as elastomers above their $T_{\mathrm{g}}$ or $T_{\mathrm{m}}$ for amorphous or semi-crystalline polymers, respectively. Thermoplastics, on the other hand, flow when heated above their $T_{\mathrm{g}}$ or $T_{\mathrm{m}}$ for amorphous or semi-crystalline polymers, respectively. The viscosity of amorphous thermoplastics sharply drops above the $T_{\mathrm{g}}$, following the Williams, Landel, and Ferry (WLF) model[54] between the $T_{\mathrm{g}}$ and approximately $100{ }^{\circ} \mathrm{C}$ above the $T_{\mathrm{g}}$; it then follows Arrhenius-type temperature dependence at higher temperatures.[55-58] In the case of semi-crystalline thermoplastics, the viscosity abruptly drops at the $T_{\mathrm{m}}$ and then follows an Arrhenian temperature dependence as long as the $T_{\mathrm{m}}$ is approximately $100{ }^{\circ} \mathrm{C}$ higher than the $T_{\mathrm{g}} .[56,58,59]$

Vitrimers behave in a strikingly different way. For vitrimers to flow, the molecular network must be able to reorganize its topology, which requires enough energy to both break the physical interactions preventing long range motion of polymer chains and to allow degenerate reactions between the dynamic links to proceed. The liquid-to-solid transition in vitrimers thus reflects either the freezing of the motion of polymer chains [47, 60-62] or the quenching of the exchange reaction.[47, 48] In the latter case, vitrimers present a new characteristic transition temperature, the $T_{\mathrm{v}}$, which is defined as the temperature at which the

melt viscosity is equal to $10^{12} \mathrm{~Pa} \cdot \mathrm{s} .[47,63]$ The $T_{\mathrm{v}}$ corresponds to the freezing of network topology due to the absence of exchange reaction on the timescale of the observation.

The position of the $T_{\mathrm{v}}$ compared to that of the $T_{\mathrm{g}}$ (and the $T_{\mathrm{m}}$ in the case of a semicrystalline vitrimer) dictates the thermo-mechanical profile of the material. For example, consider an amorphous vitrimer that has a $T_{\mathrm{v}}$ that is greater in value than its $T_{\mathrm{g}}$. When this material is heated above its $T_{\mathrm{g}}$ (Fig. 2A), it undergoes a transition from a glassy to a rubbery state. Upon further heating, the kinetics of the degenerate exchange increase, and thus the 
lifetime of the dynamic bonds proportionally decreases. Yet, within the temperature range between the $T_{\mathrm{g}}$ and $T_{\mathrm{v}}$, the material behaves as an elastomer because the exchange reactions are slow enough such that the topology remains frozen. When the temperature reaches the $T_{\mathrm{v}}$, the exchange reactions become sufficiently fast to allow macroscopic flow. The material starts to behave as a viscoelastic liquid, with a melt viscosity that gradually decreases following an Arrhenian dependence with temperature. Similarly, in the case of a semicrystalline vitrimer with a $T_{\mathrm{m}}$ lower than the $T_{\mathrm{v}}$ (Fig. $2 \mathrm{~B}$ ), the material behaves like an elastomer between the $T_{\mathrm{m}}$ and $T_{\mathrm{v}}$, and then, above the $T_{\mathrm{v}}$ like a viscoelastic liquid with a melt viscosity that gradually decreases with temperature according to Arrhenius law.

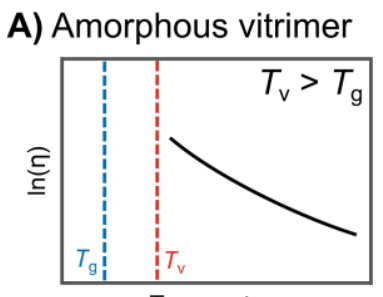

Temperature
B) Semi-crystalline vitrimer

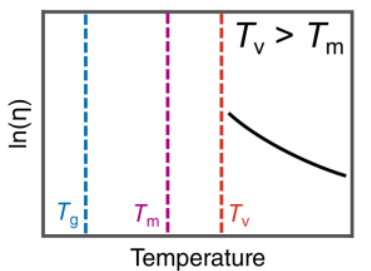

C) Amorphous vitrimer

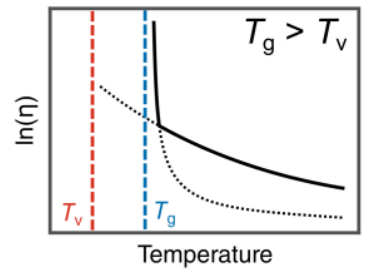

Figure 2. A) Plot of $\ln (\eta)$ versus temperature of an amorphous vitrimer in which the topology freezing transition temperature, $T_{\mathrm{v}}$, is greater than the glass transition temperature, $T_{\mathrm{g}}$. B) Plot of $\ln (\eta)$ versus temperature of a semi-crystalline vitrimer in which $T_{\mathrm{v}}$ is greater than the melting temperature, $T_{\mathrm{m}}$. C) Plot of $\ln (\eta)$ versus temperature for a vitrimer that features a $T_{\mathrm{g}}$ that is greater than its $T_{\mathrm{v}}$.

Alternatively, the hypothetical $T_{\mathrm{v}}$ of the vitrimer can be lower than the $T_{\mathrm{g}}$, causing the material to behave like a viscoelastic liquid at high temperature with a melt viscosity 
following the Arrhenius law. In such a case with an amorphous vitrimer, as the temperature is lowered and approaches the $T_{\mathrm{g}}$, the degenerate reactions are still fast while long range segmental motions of polymers become the limiting factor for the topological rearrangement of the network. The melt viscosity then deviates from an Arrhenian dependence towards WLF behavior as a function of temperature (Fig. 2C).[51, 64] When the temperature reaches the $T_{\mathrm{g}}$, the suppression of long range molecular motion induces the transition from a viscoelastic liquid to an elastic solid, as the dynamic exchangeable links are trapped in a glassy matrix. Similar considerations can be applied to semi-crystalline vitrimers as well.

Characteristic Arrhenian temperature dependence on melt viscosity has been demonstrated with various vitrimer systems relying on different types of exchangeable bonds, establishing that the melt viscosity can be controlled by manipulating the lifetime of the dynamic covalent bonds.[47, 48, 60, 61, 65-68] As an example, Leibler and co-workers[48] illustrated this principle by catalyzing the degenerate transesterification between esters and alcohols in an epoxy matrix derived from bisphenol A diglycidyl ether and a mixture of tricarboxylic and dicarboxylic fatty acids. To induce vitrimer behavior, these epoxies were loaded with varying kinds and amounts of transesterification catalysts. Their zero-shear melt viscosity, obtained from stress relaxation experiments, were compared as a function of temperature. 

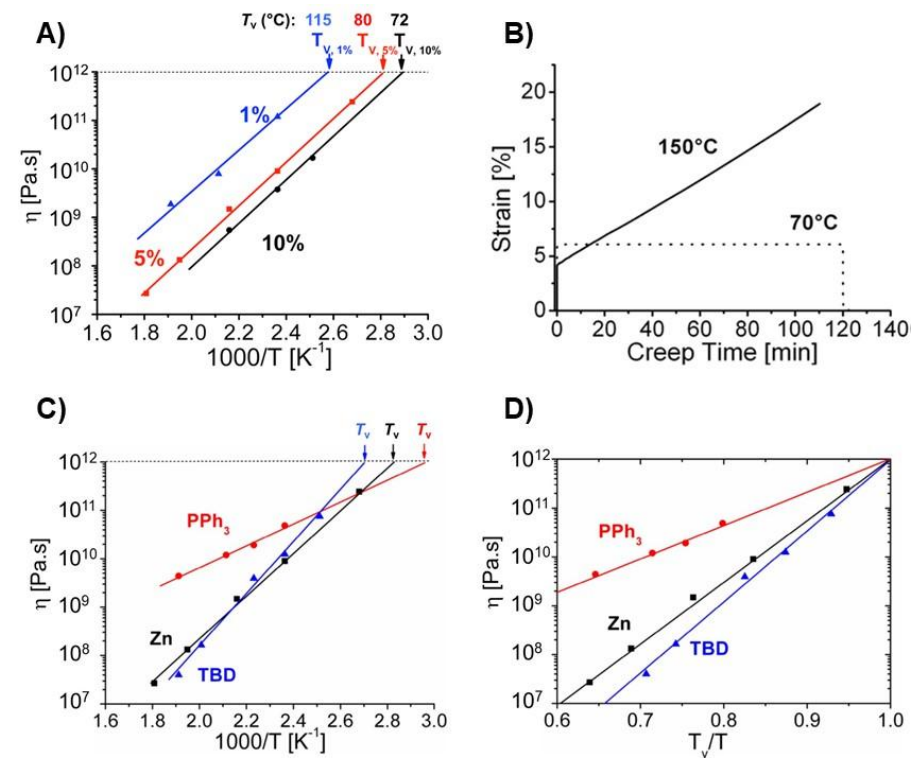

Figure 3. Viscoelastic properties of $\beta$-hydroxyl-ester vitrimers obtained from bisphenol A diglycidyl ether and a mixture of tricarboxylic and dicarboxylic fatty acids A) Arrhenius plot of the viscosity for vitrimers containing 1 (blue), 5 (red), and 10 (black) mol \% of $\mathrm{Zn}(\mathrm{OAc})_{2}$. B) Elongational creep experiments at 70 and $150{ }^{\circ} \mathrm{C}$ for a vitrimer catalyzed with $10 \mathrm{~mol} \%$ of $\mathrm{Zn}(\mathrm{OAc})_{2}$. C) Arrhenius plot of the viscosity for vitrimers containing $5 \mathrm{~mol} \%$ of $\mathrm{Zn}(\mathrm{OAc})_{2}$ (black), $\mathrm{PPh}_{3}$ (red), and TBD (blue). D) Angell fragility plot, normalized at $T_{\mathrm{v}}$, for vitrimers containing $5 \mathrm{~mol} \%$ of $\mathrm{Zn}(\mathrm{OAc})_{2}$ (black), $\mathrm{PPh}_{3}$ (red), and $\mathrm{TBD}$ (blue). [48]. Copyright 2012. Adopted with permission from the American Chemical Society.

As the loading of zinc acetate is increased (i.e., 1, 5 and $10 \mathrm{~mol} \%$ ), the zero-shear melt viscosity shifts to lower values for a given temperature, while the activation energy of the viscous flow remains unchanged (ca. $90 \mathrm{~kJ} \mathrm{~mol}^{-1}$ ) (Fig. 3A).[48] This behavior reflects the increase of the rate of exchange of the dynamic links with the catalyst concentration while the activation energy of the degenerate reaction remains the same. Increasing the catalyst loading in vitrimers thus does not modify the temperature dependence of the melt viscosity, but it allows lowering the viscosity at a given temperature, and therefore $T_{\mathrm{v}}$. In the present system, the $T_{\mathrm{v}}$ decreases from 115 , to 80 and finally $72{ }^{\circ} \mathrm{C}$, as increasing zinc acetate concentration 
from 1 , to 5 and finally $10 \mathrm{~mol} \%$.[69] In other words, increasing the catalyst loading in vitrimers affects both their processability and their temperature window of usage.

This material is expected to behave like an elastomer between its $T_{\mathrm{g}}\left(15^{\circ} \mathrm{C}\right)$ and $T_{\mathrm{v}}$, and like a viscoelastic liquid above its $T_{\mathrm{v}}$, which is clearly evident by elongation creep experiments performed at $70{ }^{\circ} \mathrm{C}$ and $150{ }^{\circ} \mathrm{C}$ with the vitrimer containing $10 \mathrm{~mol} \%$ of zinc acetate $\left(T_{\mathrm{v}}\right.$ of $\left.72{ }^{\circ} \mathrm{C}\right)$ (Fig. 3B).[48] At $70{ }^{\circ} \mathrm{C}$, the vitrimer exhibits the typical behavior of an elastic solid obeying Hooke's law. Under the application of an elongational stress, the material deforms instantaneously, with a strain equal to the ratio of the tensile stress to the elastic modulus. When the stress is removed, the material recovers its original dimension and show no sign of creep. When subjected to the same elongational stress at $150^{\circ} \mathrm{C}$, the materials show an instantaneous elastic response and then exhibits linear deformation over time, which is consistent with the vitrimer flowing like a viscoelastic liquid obeying Maxwell's law as a result of dynamic exchange reactions.

Changing the catalyst nature affects both the rate of exchange and the activation energy of degenerate reactions. In vitrimers, this translates into materials with different viscous flow activation energy (Fig. 3C). By keeping the catalyst concentration constant but changing its structure (i.e. $5 \mathrm{~mol} \%$ of either zinc acetate, triphenylphosphine, or 1,5,7triazabicyclo[4.4.0]dec-5-ene (TBD)), vitrimers with significantly different viscous flow activation energies $\left(86,43\right.$ and $106 \mathrm{~kJ} \mathrm{~mol}^{-1}$, with zinc acetate, triphenylphosphine and TBD, respectively) are accessed.[48, 69] Thus, by adjusting the nature of the catalyst and its concentration, it should be possible to design vitrimers with the same $T_{\mathrm{v}}$, i.e. the same temperature window of usage, but adjustable processability, i.e. with different melt viscosity temperature dependence (Fig. 3D).

The possibility to control the flow properties of vitrimers via the catalysis or quenching of the degenerate reactions was also demonstrated on other vitrimers relying on 
transesterification,[60, 66, 70-72] as well as by Du Prez, Winne and al.[65] and Nicolaÿ, Leibler and al. [73] on vitrimers incorporating vinylogous urethane dynamic crosslinks, confirming that manipulating the rate of exchange of the dynamic links is an efficient and powerful tool to tune the viscoelastic properties of vitrimers.[64, 67, 68, 74]

\subsection{Adhesion}

Another important property of vitrimers relates to their ability to weld objects together. Indeed, the malleability of vitrimers is conducive to obtaining a good interfacial contact, while the formation of interfacial crosslinks reinforces the polymer-polymer interface and permits the formation of strong adhesion between vitrimeric objects. In addition, the Arrhenian temperature dependence of the melt viscosity of vitrimers permits welding to be performed with or without molds, while preserving the shape of the objects to be assembled. Numerous examples of welding of vitrimers of similar chemical natures have been described in the literature.[49, 60, 75, 76] Typically, welding of vitrimers that contain a higher concentration of exchangeable links yield greater weld strength. Increasing the temperature, as well as the catalyst loading, where appropriate, accelerates welding.[49] It is important to note that functional groups at the interface of two welded vitrimers are exchanged and not consumed in the course of welding. Thus, in the case that a joint debonds, it is possible to reform the joint without modifying the surface of the vitrimer-one must simply apply the appropriate stimulus while the two surfaces are in contact to repair the weld.[49]

It was recently demonstrated that vitrimers of different natures can be assembled together.[62] High density polyethylene (HDPE) and poly(methyl methacrylate) (PMMA) vitrimers containing dioxaborolane dynamic crosslinks were welded together, even though HDPE and PMMA are incompatible and yield very weak interfaces (Fig. 4). After pressing together the two materials at $190{ }^{\circ} \mathrm{C}$ and $11 \mathrm{kPa}$ of pressure for 20 minutes, the adhesion 
between the two materials was so strong that mechanical failure occurred in the PMMA bulk material and not at the welded joint.

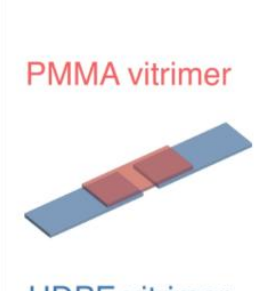

HDPE vitrimer
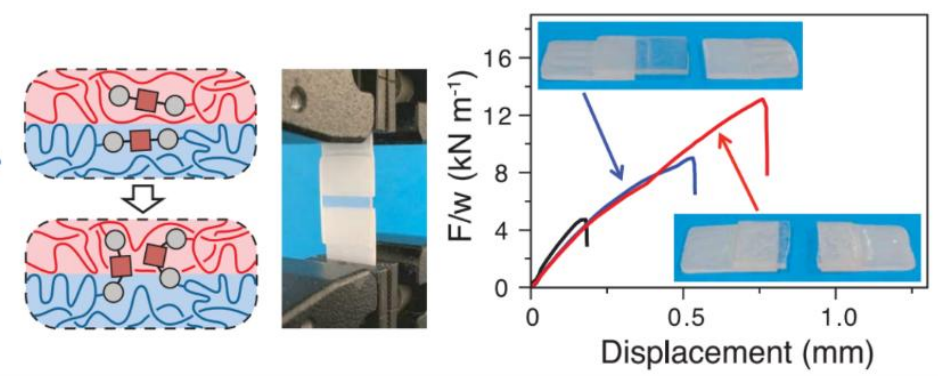

Figure 4. Adhesion between poly(methyl methacrylate) and high density polyethylene vitrimers. Displayed are a schematic representation (left), photo (center), and plot of lapshear testing results (right). In the lapshear testing plot, the PMMA/HDPE dioxaborolane thermoplastic precursors are in black (contact time $10 \mathrm{~min}$, adhesive failure), and the PMMA/HDPE vitrimers for two contact times, $10 \mathrm{~min}$ in blue (adhesive failure) and $20 \mathrm{~min}$ in red (bulk failure in the PMMA component). [62]. Copyright 2017. Adopted with permission from the American Association for the Advancement of Science.

Vitrimer composites can also be welded and assembled into new shapes, using heat as a stimulus,[77, 78] microwave radiations[79] or light, thanks to the photothermal effect of carbon nanotubes (CNT),[80] gold[81] and polydopamine[82] nanoparticles. Composites with hard and soft polyester, polyurethane, polyimine, or polydiene matrixes, incorporating glass[77] and carbon[78] fibers, as well as CNTs,[79, 80, 83] silica,[84, 85] gold,[81] or organic[82] nanoparticles can be efficiently welded, opening new opportunities to engineer advanced materials for aerospace, automotive, shipbuilding, energy, and electronics industries.

\subsection{Recyclability}


The ability to flow allows vitrimers to be reprocessed and recycled. In a typical exemplification, a vitrimer specimen is cut or ground into small pieces and then reformed into a new specimen that is evaluated by physicochemical and mechanical characterization. Multiple cycles of reprocessing and characterization are usually performed, and the recyclability is assessed by comparing the properties of the recycled vitrimers to those of the initial material. The properties that are typically evaluated include the $T_{\mathrm{g}}$, the value of the elastic modulus of the rubbery plateau, the thermal stability, the tensile properties, and the gel content.

However, the routine battery of benchmarks provides limited information on side reactions that can transform dynamic crosslinks into static crosslinks, as the formation of static crosslinks may not prevent processing by compression molding[86, 87] and can occur without changing the overall crosslinking density. This uncertainty is further accentuated by the dependency of mechanical recovery on the processing conditions. The selective cleavage of the dynamic links in vitrimers allows differentiating dynamic crosslinks from static crosslinks. Such tests give access to a precise and quantitative characterization of the molar mass, molar mass distribution, and functionality of the polymer chains constituting the vitrimer, $[62,87]$ thereby providing valuable information at the molecular level for precisely evaluating the long-term recyclability of vitrimers.

The selective cleavage of the dynamic links can also serve as a practical route to the closed-loop recycling of vitrimer composites. This approach was successfully used to quantitatively recover and separate the carbon fibers and the polymer matrix in polyimine[78] and polyester[88] vitrimer composites (Fig. 5). The reclaimed fibers and resin could be reused to produce new composites that exhibited the same mechanical properties as the original material. The selective cleavage of the dynamic links has also been successfully used to recover glass fibers in vinylogous urea based composite vitrimers.[89] 


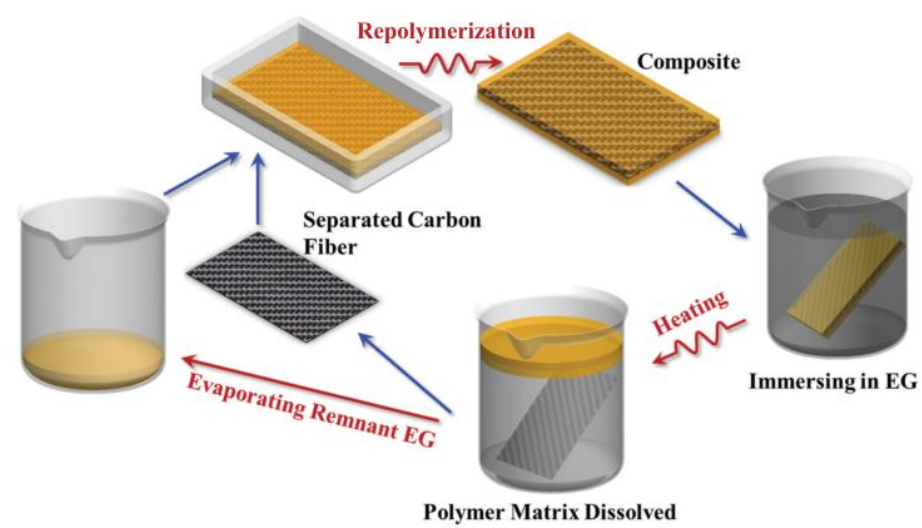

Figure 5. Recycling of a carbon fiber-reinforced vitrimer through depolymerization of the vitrimer matrix. [88]. Copyright 2017. Adopted with permission from Elsevier Science Ltd.

\section{Vitrimers: Chemistry}

\subsection{Synthetic strategies to prepare vitrimers}

There are two main strategies for preparing vitrimers-the polymerization of multifunctional monomers and the crosslinking of thermoplastics. The first strategy consists of curing a mixture of multifunctional monomers to generate a network containing dynamic covalent bonds. In the case of a step-growth process, the dynamic covalent links can be generated during network formation[31, 45, 47, 67, 90] (Fig. 6A) and/or can already be present in at least one of the monomers (Fig. 6B).[37, 91, 92] In some cases, commercial resins can be converted into vitrimers by merely adding an appropriate catalyst that facilitates exchange reactions or by adjusting the composition of the resins.[47, 65] In the case of chaingrowth polymerizations, the most direct route is to perform a copolymerization in the presence of a bifunctional crosslinker that contains a dynamic covalent bond, as exemplified by Nicolaÿ, Matyjaszewski and co-workers for vinyl monomers (Fig. 6C).[93] This strategy was also recently employed by Bates et al. to prepare polyester vitrimers through the ring opening copolymerization of 4-methylcaprolactone with a bis-lactone crosslinker.[66] 


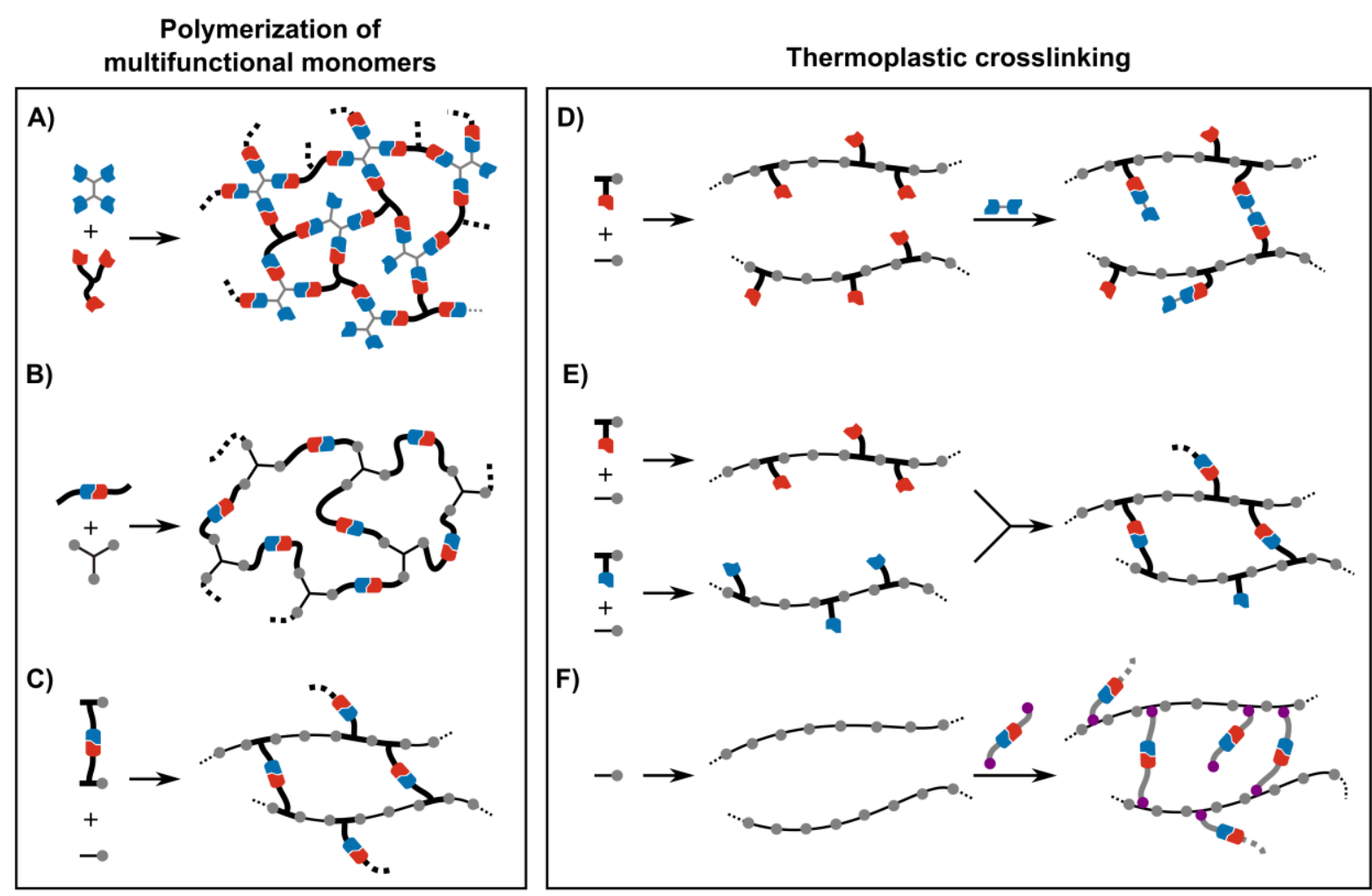

Figure 6. Synthetic strategies for creating vitrimers.

The synthesis of vitrimers from multifunctional monomers requires the dynamic covalent chemistry to be compatible with the active species involved in the polymerization, as well as with the different monomers under the conditions of the polymerization. This approach offers the advantage of yielding vitrimers in a single-step. One of the potential difficulties is the necessity to remove the unreacted monomers or residual solvent from the vitrimer. In terms of process, this approach implies going from a solution or melt to a gel or bulk network, which may be dynamic or not under the polymerization conditions.

The second approach is to transform thermoplastic polymers into vitrimers. Two main scenarios exist. In the first, the function(s) involved in the degenerate reaction are present in the backbone of the polymers or as pendant functions. The dynamic functions can be intrinsically present in the polymer, like the ester or terminal alcohol functions of polyesters, for vitrimer relying on transesterification as exchange reactions, $[60,94,95]$ or the alkene 
bond of polydienes for vitrimers relying on alkene metathesis, for example.[96] Otherwise dynamic functions can be introduced on purpose during the synthesis of the polymers, by copolymerizing a comonomer containing the exchangeable group.[62, 64, 73, 74, 97, 98] Then, the functional thermoplastic polymers are crosslinked into vitrimers, either in solution or in the melt, with a multifunctional molecule or a polymer (Figs. 6D and 6E). This approach offers the most flexibility in terms of polymer matrices, dynamic bonds, and synthesis conditions.

Existing thermoplastics can also be turned into vitrimers even if they do not carry any functions involved in the degenerate reaction. In that case, the dynamic linkages are introduced via post-polymerization functionalization (Fig. 6F).[62, 87, 99] The chemistry required to attach the crosslinkers depends on the reactivity of the parent polymers and should also be compatible with the exchangeable links. This process is particularly appealing because it directly converts conventional polymers into vitrimers without modifying the already existing and optimized syntheses. However, this approach can be very challenging due to the low reactivity of the polymers to be transformed (e.g., polyolefins and fluoropolymers) or because of their low solubility and/or high melting temperature (e.g., polyethylene terephthalate and polyamides), which significantly limit the processing parameter window. In such cases, reactive extrusion is a relevant technique to accomplish this functionalization, which typically operates via radical-initiated reactions. Nicolaÿ, Leibler, and co-workers used this strategy to introduce dioxaborolane units to prepare HDPE vitrimers.[62]

\subsection{Exchangeable chemical bonds}

The dynamic covalent bonds are directly responsible for vitrimers' characteristic properties. Numerous degenerate reactions are known, and many have been successfully used 
to prepare vitrimers. Several recent reviews provide excellent discussions of these chemistries in general, as well as in the context of vitrimers more specifically.[51-53, 100-106] In Fig. 7, a sampling of dynamic reactions are presented along with representative references for their respective synthetic implementation into vitrimers. Below we describe important practical considerations for implementing such reactions into vitrimers.

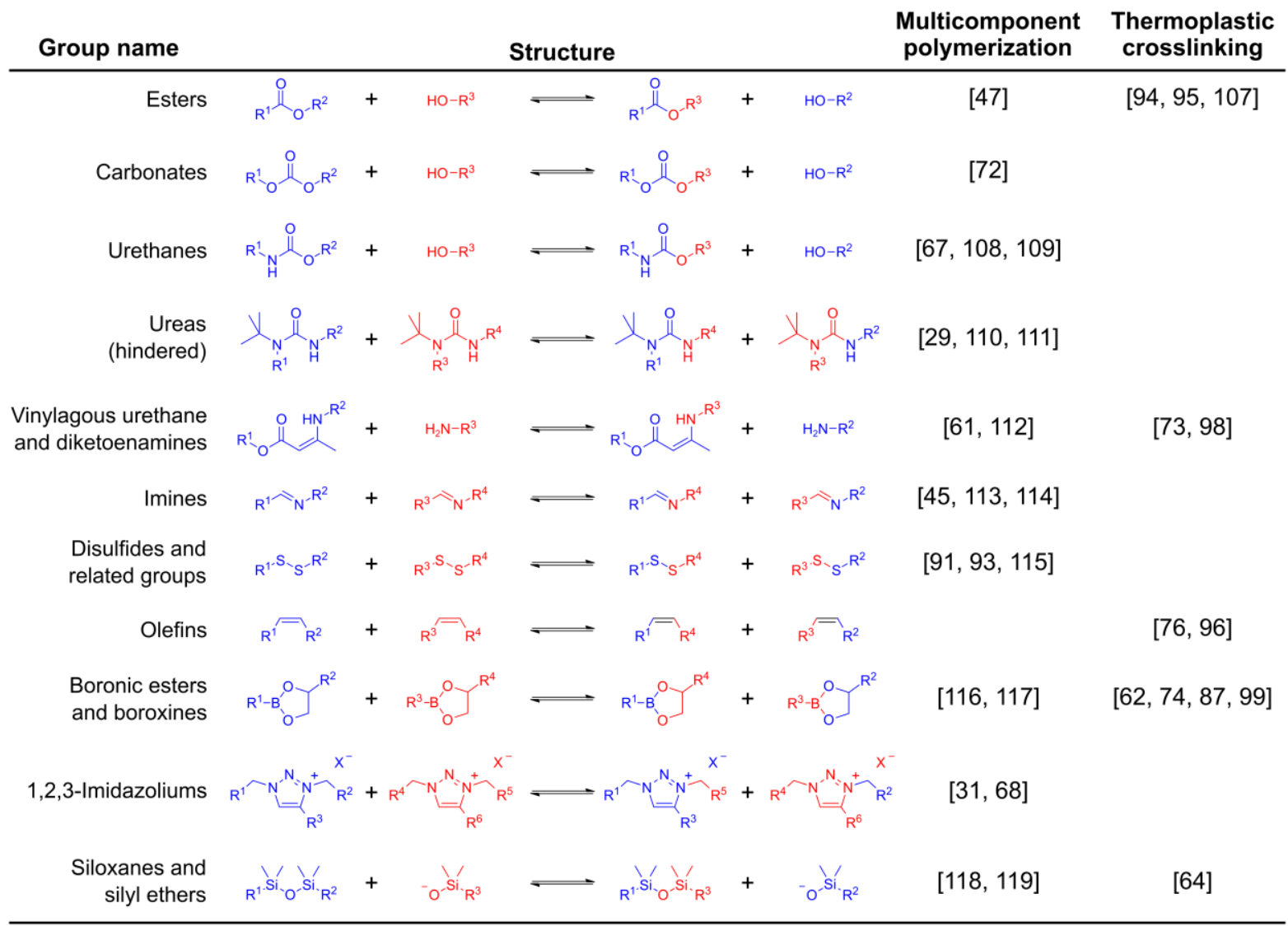

Figure 7. Selection of dynamic covalent reactions employed to make vitrimers. References are provided for representative examples of the different routes to incorporate these bond exchange reactions into vitrimers.

Some dynamic covalent reactions are more practical to use in one route over the other. For instance, many kinds of dynamic covalent bonds are already generated in thermosets that are synthesized via step growth polymerization (e.g., esters, carbonates, and urethanes). 
Given the similarity between conventional thermoset synthesis and multicomponent polymerization vitrimer synthesis (Figs. 6A, 6B, and 6C), a simple way to access vitrimers is to modify the conventional synthesis to incorporate the components or additives necessary to make the system dynamic under the desired conditions (e.g., adjusting the ratio of monomers or the addition of a catalyst). It is of course also possible to use these kinds of bonds in a thermoplastic crosslinking approach (Figs. 6D, 6E, and 6F), but it may require precautions (e.g., protection and deprotection of functional groups) to ensure that the dynamic covalent bonds are chemically orthogonal to the functionality used to create the network. In designing a vitrimer, it is essential to avoid side reactions that would consume the dynamic links during the synthesis, usage and (re)processing of the material.

The use of catalysts is an important consideration that entails tradeoffs in vitrimer design. Both the structure and concentration of the catalyst impact the lifetime of dynamic covalent bonds, $[48,60,65,66,70-72]$ making it a useful parameter for tuning the physical properties of vitrimers. However, catalysts can be susceptible to degradation and leaching over time, and toxicity concerns can preclude their use in commercial products. Some dynamic covalent reactions offer flexibility in being able to operate under catalyzed and non-catalyzed conditions. For instance, in the original report of vitrimers, [47] dynamic transesterification between ester bonds and stoichiometric number of hydroxyl groups was activated through the addition of a zinc-based catalyst. Later, Guo, Zhang, and co-workers[120] found ester-based vitrimers could be self-catalyzed by incorporating an excess of hydroxyl groups into the polymer matrix; the authors posit that the hydroxyl groups activate the ester groups via hydrogen bonding.

In some cases, it can be advantageous to deliberately introduce non-dynamic crosslinks to boost the mechanical properties. Elastomeric vitrimers, for example, would benefit at service temperature from some proportion of static crosslinks to suppress creep. The dynamic 
linkages would allow these materials to still be (re)processable and unlock self-healing capabilities. The Torkelson,[86] Sumerlin,[116] and Nicolaÿ[87] groups have demonstrated this practical approach to tuning the mechanical properties of a dynamic material.

All of these synthetic issues must be considered in tandem with the thermo-mechanical demands of the application at hand, with a focus on the processing and usage temperature windows. There is not a universally ideal behavior in terms of life-time of the dynamic bonds as a function of temperature, as all applications have their own unique demands. Thus the dynamicity of the bonds must be balanced with the physical properties of the matrix and the targeted properties.

\section{Vitrimers: present and future}

\subsection{New chemistries and synthetic routes}

Transitioning vitrimers from academic materials to industrial products is contingent upon using inexpensive feedstocks in synthetic processes that are both fast and scalable. Drop-in solutions are ideal because they require minimal modification to existing polymer syntheses and processing infrastructures. The synthesis of vitrimers by reactive processing of commercial thermoplastics with functionalized additives is thus particularly appealing. Vitrimers can be obtained without modifying existing syntheses and without adding any additional synthetic steps because the transformation is done during processing. Only a few examples of vitrimer synthesis by reactive processing of thermoplastics have been reported to date. $[62,99,121,122]$ For the future, we believe it will be advantageous to develop new grafting chemistries and dynamic covalent bonds that are compatible with this processing technique.

\subsection{Solubility}


The original description of vitrimers states that the number of chemicals bonds in the network is constant at all temperatures. This principle is the basis for a prerequisite that has been commonly invoked in previous reports to decide whether a material should be designated as a vitrimer: vitrimers should be insoluble at all temperatures.[47-49, 51] However, bond reshuffling in vitrimers can lead to the formation of loops, which can be accompanied by the release of soluble linear, cyclic and/or (hyper)branched polymers, all while maintaining a constant number of chemical bonds. Vitrimers could thus partially or completely dissolve depending on the network topology, chemical functionality, lifetime of the dynamic bond under the swelling conditions, experiment duration, solvent properties, and solvent volume fraction.

We recently confirmed this possibility with a polybutadiene vitrimers derived from polubutadiene oligomers that were functionalized with dynamic dioxaborolane crosslinks.[87] Samples with a low degree of crosslinking were highly insoluble in THF after 24 hours of immersion at room temperature (insoluble fraction of ca. $90 \%$ ), but were entirely dissolved after $120 \mathrm{~h}$. Solubility tests can thus be misleading for assessing the crosslinking density of vitrimers. Theoretical and experimental model studies should be conducted to predict and quantify the kinetics of dissolution of vitrimers as a function of the topology and functionality of the network, lifetime of the dynamic links, and solvent fraction and quality.

\subsection{Flow properties}

The development of models to reliably predict temperature-dependent melt flow properties will be invaluable because these properties are essential for designing vitrimers that can be processed with industrial equipment. A good starting point is the "sticky reptation" theory used to model the dynamics of networks and entangled solutions of polymers bearing functional groups that form transient crosslinks.[123-125] This model 
predicts that the motion of polymer chains (and thus the terminal relaxation time the reversible network) depends on the chain length, the concentration of the polymer chains, and the lifetime of the transient crosslinks.[123] At high association degree of the stickers, the activation energy for viscous flow is substantially larger than the activation energy of the isolated transient crosslink.[124, 125] This is a consequence of the low concentration of available crosslinking partners under these conditions.

Vitrimers present new wrinkles that are not yet accounted for in this model. Many vitrimers contain exchangeable links in the main chain, and thus the backbone dimension of polymer chains can change on a timescale comparable to the lifetime of the dynamic links. This phenononen will significantly impact the motion of polymer molecules. Furthermore, degenerate reactions may involve reactive partners with non-equivalent functionality, such as alcohols (monovalent) and esters (divalent) in the case of transesterification (Fig. 1B). These different groups may be present in stochiometric or non-stoichiometric ratios. For example, when pendant and terminal hydroxyl groups are in large default as compared to ester groups present in the backbone or as a crosslink, many exchange reactions may be necessary before a dynamic ester bonds linking two polymer chains is exchanged. This situation should lead to vitrimers with a viscous flow activation energy significantly larger than that of the analogous small molecule degenerate exchange. On the contrary, when both types of bonds are present in an equimolar ratio and at a high concentration, the viscous flow activation energy of the vitrimers is comparable to that of the exchange reaction on small model molecules. This hypothesis is consistent with the reported relaxation of $\beta$-hydroxy ester based vitrimers (with equimolar hydroxyl and ester groups)[47] and polylactide vitrimers (with an excess of ester groups compared to hydroxyl groups)[60]. The development of a theory that could account for such behavior would be a useful tool in designing the dynamics of vitrimers for specific applications. 
A related challenge is to develop new protocols for quantitatively describing the intrinsic properties of vitrimers. Given that the $T_{\mathrm{v}}$ is defined as the temperature at which the melt viscosity is $10^{12} \mathrm{~Pa} \cdot \mathrm{s}$, the methods most commonly used to determine this value are dilatometry, stress-relaxation, and creep experiments. All of these experiments require the sample to be subjected to an external force. Although relevant for material processing applications, such measurements are not appropriate for understanding the material under static conditions, which can be critical for self-healing. Wei, Ji and co-workers[126] reported a new protocol that makes use of aggregation-induced-emission (AIE) as an alternative means to probe the topology freezing temperature of vitrimers. The fluorescence intensity of a AIE probe dispersed in a vitrimer matrix is correlated with a $T_{\mathrm{v}}$ under static conditions. We expect future research to further explore new protocols for quantifying the relationships between temperature, exchange kinetics, and mechanical properties, permitting deeper insight into the underlying chemical and physical properties of vitrimers.

\subsection{Advanced vitrimers}

The concept of vitrimers has addressed limitations of many old concepts and opened doors to new possibilities. For example, shape memory materials based on conventional thermosets were initially limited by the inability to program more than one permanent shape. The introduction of vitrimer chemistry to this application overcomes this limitation, as vitrimers can shuffle their topology to accommodate the programming of a new "permanent" shape when heated above the $T_{\mathrm{v}}$.[75] For similar reasons, vitrimers have unlocked new possibilities in the field of liquid crystalline actuators, which are valuable for applications of mechanical actuation such as synthetic muscles or valves in microfluidic systems.[127, 128]

A better understanding of the correlation linking the structure and the functionality of vitrimers with their dynamics will greatly facilitate the rational design of advanced vitrimers. 
Already exciting contributions toward this goal have been made. As mentioned above, the groups of Torkelson,[86] Sumerlin,[116] and Nicolaÿ[87] have recently reported how introducing a proportion of non-dynamic crosslinks gives rise to improved creep resistance. Alternatively, the incorporation of two (or more) kinds of dynamic links with different lifetimes (e.g., one very short at service temperature and one dynamic only at processing tempertaure) is an elegant path to tuning a vitrimer's viscoelasticy profile.[129, 130] Ricarte, Leibler and co-workers[131] recently described the consequences of phase separation between polyethylene domains and grafted boronic ester domains in polyethylene vitrimers. Sumerlin and colleagues[132] recently showed how the microphase separation of welldefined vitrimer block copolymers gives rise to enhanced creep resistance, representing another vital tool for controlling vitrimer viscoelastic properties.

The implementaiton of all these principles into new dynamic and responsive devices is a promising approach to valorizing vitrimer technology. Examples include biomedical devices,[133] 3D prinitng,[134, 135] and photolithography applications.[136] We anticipate that new relationships between vitrimer chemistry and old concepts of polymer chemistry will continue to drive innovation. We hope that this technology will ultimately spur completely new ideas that contribute to the next great expansion to the frontier of polymer chemistry.

\section{Conclusion}

Vitrimers are materials of contrast. They are permanent networks of polymer chains, yet the topology of this network can change in response to external stimuli. The crux of this behavior is the dynamic covalent bonds that hold the polymer network together; the unique macroscopic properties of vitrimers are based on the lifetime of these bonds as a function of temperature. The primary advantage of this approach is that vitrimers exhibit properties that 
were previously thought to be mutually exclusing-vitrimers are processable like thermoplastics, but at the same time feature the robust mechanical properties of thermosets. Since the groundbreaking contribution of Leibler and co-workers[47] in 2011, much progress has been made on developing the underlying chemistry of vitrimers and prototyping them in commercially relevant applications. However, there are clear obstacles that must be overcome to produce these materials in industry, which encompass design principles, synthesis, processing, and recycling. We are optimistic that the polymer chemistry and physics communities will continue to push the concept of vitrimers forward and harness it to make sustainable high performance materials.

\section{References}

\begin{tabular}{|c|c|c|c|c|c|}
\hline 1 & 2 & 3 & 4 & 5 & 6 \\
\hline [1] & Staudinger $\mathrm{H}$. & Über Polymerisation. & $\begin{array}{l}\text { Ber Dtsch Chem Ges } \\
\text { A B Ser }\end{array}$ & 1920 & ;53:1073-85. \\
\hline$[2]$ & Staudinger $\mathrm{H}$, Fritschi J. & $\begin{array}{l}\text { Über die Hydrierung des } \\
\text { Kautschuks und Iber seine } \\
\text { Konstitution. }\end{array}$ & Helv Chim Acta & 1922 & ;5:785-806. \\
\hline [3] & Hawker CJ, Wooley KL. & $\begin{array}{l}\text { The Convergence of Synthetic } \\
\text { Organic and Polymer } \\
\text { Chemistries. }\end{array}$ & Science & 2005 & ;309:1200-5. \\
\hline [4] & Matyjaszewski K. & $\begin{array}{l}\text { Macromolecular engineering: } \\
\text { From rational design through } \\
\text { precise macromolecular } \\
\text { synthesis and processing to } \\
\text { targeted macroscopic material } \\
\text { properties. }\end{array}$ & Prog Polym Sci & 2005 & ;30:858-75. \\
\hline [5] & $\begin{array}{l}\text { Hadjichristidis N, latrou } \\
\text { H, Pitsikalis M, Mays J. }\end{array}$ & $\begin{array}{l}\text { Macromolecular architectures } \\
\text { by living and controlled/living } \\
\text { polymerizations. }\end{array}$ & Prog Polym Sci & 2006 & ;31:1068-132. \\
\hline [6] & $\begin{array}{l}\text { Domski GJ, Rose JM, } \\
\text { Coates GW, Bolig AD, } \\
\text { Brookhart M. }\end{array}$ & $\begin{array}{l}\text { Living alkene polymerization: } \\
\text { New methods for the precision } \\
\text { synthesis of polyolefins. }\end{array}$ & Prog Polym Sci & 2007 & ;32:30-92. \\
\hline [7] & Sumerlin BS, Vogt AP. & $\begin{array}{l}\text { Macromolecular Engineering } \\
\text { through Click Chemistry and } \\
\text { Other Efficient } \\
\text { Transformations. }\end{array}$ & Macromolecules & 2010 & ;43:1-13. \\
\hline [8] & Meijer HEH, Govaert LE. & $\begin{array}{l}\text { Mechanical performance of } \\
\text { polymer systems: The relation } \\
\text { between structure and } \\
\text { properties. }\end{array}$ & Prog Polym Sci & 2005 & ;30:915-38. \\
\hline
\end{tabular}




\begin{tabular}{|c|c|c|c|c|c|}
\hline [9] & Leibler L. & $\begin{array}{l}\text { Nanostructured plastics: Joys of } \\
\text { self-assembling. }\end{array}$ & Prog Polym Sci & 2005 & ;30:898-914. \\
\hline [10] & Ruzette AV, Leibler L. & $\begin{array}{l}\text { Block copolymers in } \\
\text { tomorrow's plastics. }\end{array}$ & Nat Mater & 2005 & ;4:19-31. \\
\hline [11] & De Gennes PG. & $\begin{array}{l}\text { Scaling Concepts in Polymer } \\
\text { Physics. }\end{array}$ & $\begin{array}{l}\text { Ithaca: Cornell Univ } \\
\text { Press, }\end{array}$ & 1979 & .319 pp. \\
\hline [12] & Doi M, Edwards SF. & $\begin{array}{l}\text { The Theory of Polymer } \\
\text { Dynamics. }\end{array}$ & $\begin{array}{l}\text { Oxford:Oxford } \\
\text { University Press, }\end{array}$ & 1988 & $406 \mathrm{pp}$. \\
\hline [13] & Ferry JD. & $\begin{array}{l}\text { Viscoelastic Properties of } \\
\text { Polymers. 3rd Ed. }\end{array}$ & $\begin{array}{l}\text { New York: John } \\
\text { Wiley \& Sons Inc, }\end{array}$ & 1980 & 672 pp. \\
\hline [14] & Biron M. & $\begin{array}{l}\text { Thermoplastics and } \\
\text { Thermoplastic Composites: } \\
\text { Technical Information for } \\
\text { Plastics Users. }\end{array}$ & $\begin{array}{l}\text { Amsterdam: } \\
\text { Elsevier Ltd, }\end{array}$ & 2007 & .944 pp. \\
\hline [15] & Biron M. & $\begin{array}{l}\text { Thermosets and Composites: } \\
\text { Technical Information for } \\
\text { Plastics Users. }\end{array}$ & $\begin{array}{l}\text { Amsterdam: } \\
\text { Elsevier Ltd, }\end{array}$ & 2003 & .536 pp. \\
\hline [16] & Morales Ibarra R. & $\begin{array}{l}\text { Recycling of thermosets and } \\
\text { their composites. }\end{array}$ & $\begin{array}{l}\text { In: Guo Q, editor. } \\
\text { Thermosets. } \\
\text { Structure, } \\
\text { Properties and } \\
\text { Applications. 2nd } \\
\text { Ed. Amsterdam: } \\
\text { Elsevier Ltd, }\end{array}$ & 2018 & p. 639-66. \\
\hline [17] & Spontak RJ, Patel NP. & $\begin{array}{l}\text { Thermoplastic elastomers: } \\
\text { fundamentals and applications. }\end{array}$ & $\begin{array}{l}\text { Curr Opin Colloid } \\
\text { Interface Sci }\end{array}$ & 2000 & ;5:334-41. \\
\hline [18] & $\begin{array}{l}\text { Holden G, Kricheldorf HR, } \\
\text { Quirk RP. }\end{array}$ & $\begin{array}{l}\text { Thermoplastic Elastomers. 3rd } \\
\text { Ed. }\end{array}$ & $\begin{array}{l}\text { Munich: Hanser } \\
\text { Pub, }\end{array}$ & 2004 & $540 \mathrm{pp}$. \\
\hline [19] & Seiffert S, Sprakel J. & $\begin{array}{l}\text { Physical chemistry of } \\
\text { supramolecular polymer } \\
\text { networks. }\end{array}$ & Chem Soc Rev & 2012 & ;41:909-30. \\
\hline [20] & Fox JD, Rowan SJ. & $\begin{array}{l}\text { Supramolecular } \\
\text { Polymerizations and Main- } \\
\text { Chain Supramolecular } \\
\text { Polymers. }\end{array}$ & Macromolecules & 2009 & ;42:6823-35. \\
\hline$[21]$ & $\begin{array}{l}\text { Wojtecki RJ, Meador MA, } \\
\text { Rowan SJ. }\end{array}$ & $\begin{array}{l}\text { Using the dynamic bond to } \\
\text { access macroscopically } \\
\text { responsive structurally dynamic } \\
\text { polymers. }\end{array}$ & Nat Mater & 2011 & ;10:14-27. \\
\hline$[22]$ & $\begin{array}{l}\text { Cordier P, Tournilhac F, } \\
\text { Soulié-Ziakovic C, Leibler } \\
\text { L. }\end{array}$ & $\begin{array}{l}\text { Self-healing and } \\
\text { thermoreversible rubber from } \\
\text { supramolecular assembly. }\end{array}$ & Nature & 2008 & ;451:977-80. \\
\hline [23] & $\begin{array}{l}\text { Burattini S, Greenland } \\
\text { BW, Merino DH, Weng W, } \\
\text { Seppala J, Colquhoun HM, } \\
\text { et al. }\end{array}$ & $\begin{array}{l}\text { A Healable Supramolecular } \\
\text { Polymer Blend Based on } \\
\text { Aromatic } \pi-\pi \text { Stacking and } \\
\text { Hydrogen-Bonding Interactions. }\end{array}$ & J Am Chem Soc & 2010 & ;132:12051-8. \\
\hline [24] & $\begin{array}{l}\text { Burnworth M, Tang L, } \\
\text { Kumpfer JR, Duncan AJ, } \\
\text { Beyer FL, Fiore GL, et al. }\end{array}$ & $\begin{array}{l}\text { Optically healable } \\
\text { supramolecular polymers. }\end{array}$ & Nature & 2011 & ;472:334-7. \\
\hline [25] & Craven JM. & $\begin{array}{l}\text { Crosslinked thermally } \\
\text { reversible polymers from } \\
\text { condensation polymers with } \\
\text { pendant furan groups } \\
\text { crosslinked with maleimides. }\end{array}$ & $\begin{array}{l}\text { US } 3435003 \mathrm{~A} \text {. El du } \\
\text { Pont de Nemours } \\
\text { and Co }\end{array}$ & 1969 & $.5 \mathrm{pp}$ \\
\hline
\end{tabular}




\begin{tabular}{|c|c|c|c|c|c|}
\hline$[26]$ & $\begin{array}{l}\text { Chen X, Dam MA, Ono K, } \\
\text { Mal A, Shen H, Nut SR, et } \\
\text { al. }\end{array}$ & $\begin{array}{l}\text { A thermally re-mendable cross- } \\
\text { linked polymeric material. }\end{array}$ & Science & 2002 & ;295:1698-702. \\
\hline [27] & $\begin{array}{l}\text { Higaki Y, Otsuka H, } \\
\text { Takahara A. }\end{array}$ & $\begin{array}{l}\text { A thermodynamic polymer } \\
\text { crosslinking system based on } \\
\text { radically exchangeable covalent } \\
\text { bonds. }\end{array}$ & Macromolecules & 2006 & ;39:2121-5. \\
\hline [28] & $\begin{array}{l}\text { Delebecq E, Pascault JP, } \\
\text { Boutevin B, Ganachaud F. }\end{array}$ & $\begin{array}{l}\text { On the Versatility of } \\
\text { Urethane/Urea Bonds: } \\
\text { Reversibility, Blocked } \\
\text { Isocyanate, and Non-isocyanate } \\
\text { Polyurethane. }\end{array}$ & Chem Rev & 2013 & ;113:80-118. \\
\hline [29] & Ying H, Zhang Y, Cheng J. & $\begin{array}{l}\text { Dynamic urea bond for the } \\
\text { design of reversible and self- } \\
\text { healing polymers. }\end{array}$ & Nat Commun & 2014 & ;5:4218/1-9. \\
\hline [30] & $\begin{array}{l}\text { Billiet S, De Bruycker K, } \\
\text { Driessen F, Goossens H, } \\
\text { Van Speybroeck V, Winne } \\
\text { JM, et al. }\end{array}$ & $\begin{array}{l}\text { Triazolinediones enable } \\
\text { ultrafast and reversible click } \\
\text { chemistry for the design of } \\
\text { dynamic polymer systems. }\end{array}$ & Nat Chem & 2014 & ;6:815-21. \\
\hline [31] & $\begin{array}{l}\text { Obadia MM, } \\
\text { Mudraboyina BP, Serghei } \\
\text { A, Montarnal D, } \\
\text { Drockenmuller E. }\end{array}$ & $\begin{array}{l}\text { Reprocessing and Recycling of } \\
\text { Highly Cross-Linked lon- } \\
\text { Conducting Networks through } \\
\text { Transalkylation Exchanges of C- } \\
\text { N Bonds. }\end{array}$ & J Am Chem Soc & 2015 & ;137:6078-83. \\
\hline$[32]$ & $\begin{array}{l}\text { Chakma P, Digby ZA, } \\
\text { Shulman MP, Kuhn LR, } \\
\text { Morley CN, Sparks JL, et } \\
\text { al. }\end{array}$ & $\begin{array}{l}\text { Anilinium Salts in Polymer } \\
\text { Networks for Materials with } \\
\text { Mechanical Stability and Mild } \\
\text { Thermally Induced Dynamic } \\
\text { Properties. }\end{array}$ & ACS Macro Lett & 2019 & ;8:95-100. \\
\hline [33] & $\begin{array}{l}\text { Trenor SR, Shultz AR, } \\
\text { Love BJ, Long TE. }\end{array}$ & $\begin{array}{l}\text { Coumarins in Polymers: From } \\
\text { Light Harvesting to Photo- } \\
\text { Cross-Linkable Tissue Scaffolds. }\end{array}$ & Chem Rev & 2004 & ;104:3059-77. \\
\hline [34] & $\begin{array}{l}\text { Zhao D, Ren B, Liu S, Liu } \\
\text { X, Tong Z. }\end{array}$ & $\begin{array}{l}\text { A novel photoreversible } \\
\text { poly(ferrocenylsilane) with } \\
\text { coumarin side group: synthesis, } \\
\text { characterization, and } \\
\text { electrochemical activities. }\end{array}$ & Chem Commun & 2006 & :779-81. \\
\hline [35] & Nagata M, Yamamoto Y. & $\begin{array}{l}\text { Photoreversible poly(ethylene } \\
\text { glycol)s with pendent coumarin } \\
\text { group and their hydrogels. }\end{array}$ & React Funct Polym & 2008 & ;68:915-21. \\
\hline [36] & $\begin{array}{l}\text { Amamoto Y, Kamada J, } \\
\text { Otsuka H, Takahara A, } \\
\text { Matyjaszewski K. }\end{array}$ & $\begin{array}{l}\text { Repeatable Photoinduced Self- } \\
\text { Healing of Covalently Cross- } \\
\text { Linked Polymers through } \\
\text { Reshuffling of Trithiocarbonate } \\
\text { Units. }\end{array}$ & Angew Chem, Int Ed & 2011 & ;50:1660-3. \\
\hline [37] & $\begin{array}{l}\text { Fairbanks BD, Singh SP, } \\
\text { Bowman CN, Anseth KS. }\end{array}$ & $\begin{array}{l}\text { Photodegradable, } \\
\text { Photoadaptable Hydrogels via } \\
\text { Radical-Mediated Disulfide } \\
\text { Fragmentation Reaction. }\end{array}$ & Macromolecules & 2011 & ;44:2444-50. \\
\hline [38] & $\begin{array}{l}\text { Imato K, Nishihara M, } \\
\text { Kanehara T, Amamoto Y, } \\
\text { Takahara A, Otsuka H. }\end{array}$ & $\begin{array}{l}\text { Self-Healing of Chemical Gels } \\
\text { Cross-Linked by } \\
\text { Diarylbibenzofuranone-Based } \\
\text { Trigger-Free Dynamic Covalent } \\
\text { Bonds at Room Temperature. }\end{array}$ & Angew Chem Int Ed & 2012 & ;51:1138-42. \\
\hline [39] & $\begin{array}{l}\text { Ivanov AE, Larsson } \mathrm{H} \text {, } \\
\text { Galaev IY, Mattiasson B. }\end{array}$ & $\begin{array}{l}\text { Synthesis of boronate- } \\
\text { containing copolymers of } \mathrm{N}, \mathrm{N} \text { - } \\
\text { dimethylacrylamide, their } \\
\text { interaction with poly(vinyl }\end{array}$ & Polymer & 2004 & ;45:2495-505. \\
\hline
\end{tabular}




\begin{tabular}{|c|c|c|c|c|c|}
\hline & & $\begin{array}{l}\text { alcohol) and rheological } \\
\text { behaviour of the gels. }\end{array}$ & & & \\
\hline$[40]$ & $\begin{array}{l}\text { Roberts MC, Hanson MC, } \\
\text { Massey AP, Karren EA, } \\
\text { Kiser PF. }\end{array}$ & $\begin{array}{l}\text { Dynamically restructuring } \\
\text { hydrogel networks formed with } \\
\text { reversible covalent crosslinks. }\end{array}$ & Adv Mater & 2007 & ;19:2503-7. \\
\hline [41] & Jackson AW, Fulton DA. & $\begin{array}{l}\text { Triggering Polymeric } \\
\text { Nanoparticle Disassembly } \\
\text { through the Simultaneous } \\
\text { Application of Two Different } \\
\text { Stimuli. }\end{array}$ & Macromolecules & 2012 & ;45:2699-708. \\
\hline [42] & $\begin{array}{l}\text { Tsarevsky NV, } \\
\text { Matyjaszewski K. }\end{array}$ & $\begin{array}{l}\text { Combining Atom Transfer } \\
\text { Radical Polymerization and } \\
\text { Disulfide/Thiol Redox } \\
\text { Chemistry: A Route to Well- } \\
\text { Defined (Bio)degradable } \\
\text { Polymeric Materials. }\end{array}$ & Macromolecules & 2005 & ;38:3087-92. \\
\hline [43] & $\begin{array}{l}\text { Deng G, Tang C, Li F, Jiang } \\
\text { H, Chen Y. }\end{array}$ & $\begin{array}{l}\text { Covalent Cross-Linked Polymer } \\
\text { Gels with Reversible Sol-Gel } \\
\text { Transition and Self-Healing } \\
\text { Properties. }\end{array}$ & Macromolecules & 2010 & ;43:1191-4. \\
\hline [44] & $\begin{array}{l}\text { Deng G, Li F, Yu H, Liu F, } \\
\text { Liu C, Sun W, et al. }\end{array}$ & $\begin{array}{l}\text { Dynamic Hydrogels with an } \\
\text { Environmental Adaptive Self- } \\
\text { Healing Ability and Dual } \\
\text { Responsive Sol-Gel Transitions. }\end{array}$ & ACS Macro Lett & 2012 & ;1:275-9. \\
\hline [45] & $\begin{array}{l}\text { Taynton P, Yu K, } \\
\text { Shoemaker RK, Jin Y, Qi } \\
\text { HJ, Zhang W. }\end{array}$ & $\begin{array}{l}\text { Heat- or Water-Driven } \\
\text { Malleability in a Highly } \\
\text { Recyclable Covalent Network } \\
\text { Polymer. }\end{array}$ & Adv Mater & 2014 & ;26:3938-42. \\
\hline$[46]$ & $\begin{array}{l}\text { Li Q, Ma S, Wang S, Yuan } \\
\text { W, Xu X, Wang B, et al. }\end{array}$ & $\begin{array}{l}\text { Facile catalyst-free synthesis, } \\
\text { exchanging, and hydrolysis of } \\
\text { an acetal motif for dynamic } \\
\text { covalent networks. }\end{array}$ & J Mater Chem A & 2019 & ;7:18039-49. \\
\hline [47] & $\begin{array}{l}\text { Montarnal D, Capelot M, } \\
\text { Tournilhac F, Leibler L. }\end{array}$ & $\begin{array}{l}\text { Silica-Like Malleable Materials } \\
\text { from Permanent Organic } \\
\text { Networks. }\end{array}$ & Science & 2011 & ;334:965-8. \\
\hline [48] & $\begin{array}{l}\text { Capelot M, Unterlass } \\
\text { MM, Tournilhac F, Leibler } \\
\text { L. }\end{array}$ & $\begin{array}{l}\text { Catalytic Control of the Vitrimer } \\
\text { Glass Transition. }\end{array}$ & ACS Macro Lett & 2012 & ;1:789-92. \\
\hline [49] & $\begin{array}{l}\text { Capelot M, Montarnal D, } \\
\text { Tournilhac F, Leibler L. }\end{array}$ & $\begin{array}{l}\text { Metal-Catalyzed } \\
\text { Transesterification for Healing } \\
\text { and Assembling of Thermosets. }\end{array}$ & J Am Chem Soc & 2012 & ;134:7664-7. \\
\hline [50] & Skene WG, Lehn JM. & $\begin{array}{l}\text { Dynamers: Polyacylhydrazone } \\
\text { reversible covalent polymers, } \\
\text { component exchange, and } \\
\text { constitutional diversity. }\end{array}$ & $\begin{array}{l}\text { Proc Natl Acad Sci } \\
\text { USA }\end{array}$ & 2004 & ;101:8270-5. \\
\hline [51] & $\begin{array}{l}\text { Denissen W, Winne JM, } \\
\text { Du Prez FE. }\end{array}$ & $\begin{array}{l}\text { Vitrimers: permanent organic } \\
\text { networks with glass-like } \\
\text { fluidity. }\end{array}$ & Chem Sci & 2016 & ;7:30-8. \\
\hline [52] & Kloxin CJ, Bowman CN. & $\begin{array}{l}\text { Covalent adaptable networks: } \\
\text { smart, reconfigurable and } \\
\text { responsive network systems. }\end{array}$ & Chem Soc Rev & 2013 & ;42:7161-73. \\
\hline
\end{tabular}




\begin{tabular}{|c|c|c|c|c|c|}
\hline$[53]$ & $\begin{array}{l}\text { Zhang ZP, Rong MZ, } \\
\text { Zhang MQ. }\end{array}$ & $\begin{array}{l}\text { Polymer engineering based on } \\
\text { reversible covalent chemistry: } \\
\text { A promising innovative } \\
\text { pathway towards new } \\
\text { materials and new } \\
\text { functionalities. }\end{array}$ & Prog Polym Sci & 2018 & ;80:39-93. \\
\hline$[54]$ & $\begin{array}{l}\text { Williams ML, Landel RF, } \\
\text { Ferry JD. }\end{array}$ & $\begin{array}{l}\text { The Temperature Dependence } \\
\text { of Relaxation Mechanisms in } \\
\text { Amorphous Polymers and } \\
\text { Other Glass-forming Liquids. }\end{array}$ & J Am Chem Soc & 1955 & ;77:3701-7. \\
\hline$[55]$ & Ngai KL, Plazek DJ. & $\begin{array}{l}\text { Relation of internal rotational } \\
\text { isomerism barriers to the flow } \\
\text { activation energy of entangled } \\
\text { polymer melts in the high- } \\
\text { temperature Arrhenius region. }\end{array}$ & $\begin{array}{l}\text { J Polym Sci Polym } \\
\text { Phys Ed }\end{array}$ & 1985 & ;23:2159-80. \\
\hline$[56]$ & $\begin{array}{l}\text { Lohse DJ, Milner ST, } \\
\text { Fetters LJ, Xenidou M, } \\
\text { Hadjichristidis N, } \\
\text { Mendelson RA, et al. }\end{array}$ & $\begin{array}{l}\text { Well-Defined, Model Long } \\
\text { Chain Branched Polyethylene. } \\
\text { 2. Melt Rheological Behavior. }\end{array}$ & Macromolecules & 2002 & ;35:3066-75. \\
\hline [57] & $\begin{array}{l}\text { Liu CY, He J, Keunings R, } \\
\text { Bailly C. }\end{array}$ & $\begin{array}{l}\text { New Linearized Relation for the } \\
\text { Universal Viscosity- } \\
\text { Temperature Behavior of } \\
\text { Polymer Melts. }\end{array}$ & Macromolecules & 2006 & ;39:8867-9. \\
\hline$[58]$ & Morris B. & $\begin{array}{l}\text { The Science and Technology of } \\
\text { Flexible Packaging. 1st ed. } \\
\text { Chapt 5. Rheology of Polymer } \\
\text { Melts. }\end{array}$ & $\begin{array}{l}\text { Amsterdam: } \\
\text { Elsevier Ltd. }\end{array}$ & 2016 & .p. $121-148$. \\
\hline [59] & $\begin{array}{l}\text { Isayev Al, Chan TW, } \\
\text { Gmerek M, Shimojo K. }\end{array}$ & $\begin{array}{l}\text { Injection molding of } \\
\text { semicrystalline polymers. II. } \\
\text { Modeling and experiments. }\end{array}$ & J Appl Polym Sci & 1995 & ;55:821-38. \\
\hline$[60]$ & $\begin{array}{l}\text { Brutman JP, Delgado PA, } \\
\text { Hillmyer MA. }\end{array}$ & Polylactide Vitrimers. & ACS Macro Lett & 2014 & ;3:607-10. \\
\hline$[61]$ & $\begin{array}{l}\text { Denissen W, Rivero G, } \\
\text { Nicolay R, Leibler L, } \\
\text { Winne JM, Du Prez FE. }\end{array}$ & Vinylogous Urethane Vitrimers. & Adv Funct Mater & 2015 & ;25:2451-7. \\
\hline$[62]$ & $\begin{array}{l}\text { Röttger M, Domenech T, } \\
\text { van der Weegen R, } \\
\text { Breuillac A, Nicolaÿ R, } \\
\text { Leibler L. }\end{array}$ & $\begin{array}{l}\text { High-performance vitrimers } \\
\text { from commodity } \\
\text { thermoplastics through } \\
\text { dioxaborolane metathesis. }\end{array}$ & Science & 2017 & ;356:62-5. \\
\hline$[63]$ & Dyre JC. & $\begin{array}{l}\text { Colloquium: the glass transition } \\
\text { and elastic models of glass- } \\
\text { forming liquids. }\end{array}$ & Rev Mod Phys & 2006 & ;78:953-72. \\
\hline$[64]$ & $\begin{array}{l}\text { Nishimura Y, Chung J, } \\
\text { Muradyan H, Guan Z. }\end{array}$ & $\begin{array}{l}\text { Silyl Ether as a Robust and } \\
\text { Thermally Stable Dynamic } \\
\text { Covalent Motif for Malleable } \\
\text { Polymer Design. }\end{array}$ & J Am Chem Soc & 2017 & ;139:14881-4. \\
\hline$[65]$ & $\begin{array}{l}\text { Denissen W, Droesbeke } \\
\text { M, Nicolaÿ R, Leibler L, } \\
\text { Winne JM, Du Prez FE. }\end{array}$ & $\begin{array}{l}\text { Chemical control of the } \\
\text { viscoelastic properties of } \\
\text { vinylogous urethane vitrimers. }\end{array}$ & Nat Commun & 2017 & ;8:14857-63. \\
\hline$[66]$ & $\begin{array}{l}\text { Self JL, Dolinski ND, Zayas } \\
\text { MS, Read de Alaniz J, } \\
\text { Bates CM. }\end{array}$ & $\begin{array}{l}\text { Bronsted-Acid-Catalyzed } \\
\text { Exchange in Polyester Dynamic } \\
\text { Covalent Networks. }\end{array}$ & ACS Macro Lett & 2018 & ;7:817-21. \\
\hline$[67]$ & $\begin{array}{l}\text { Fortman DJ, Brutman JP, } \\
\text { Cramer CJ, Hillmyer MA, } \\
\text { Dichtel WR. }\end{array}$ & $\begin{array}{l}\text { Mechanically Activated, } \\
\text { Catalyst-Free } \\
\text { Polyhydroxyurethane Vitrimers. }\end{array}$ & J Am Chem Soc & 2015 & ;137:14019-22. \\
\hline [68] & $\begin{array}{l}\text { Obadia MM, Jourdain A, } \\
\text { Cassagnau P, Montarnal } \\
\text { D, Drockenmuller E. }\end{array}$ & $\begin{array}{l}\text { Tuning the Viscosity Profile of } \\
\text { lonic Vitrimers Incorporating } \\
\text { 1,2,3-Triazolium Cross-Links. }\end{array}$ & Adv Funct Mater & 2017 & ;27:1703258. \\
\hline
\end{tabular}




\begin{tabular}{|c|c|c|c|c|c|}
\hline [69] & Capelot M. & $\begin{array}{l}\text { Chimie de Polycondensation, } \\
\text { Polymères Supramoléculaires } \\
\text { et Vitrimères. }\end{array}$ & $\begin{array}{l}\text { PhD Thesis. Paris: } \\
\text { Univ Pierre and } \\
\text { Marie Curie, }\end{array}$ & 2013 & 283 pp. \\
\hline [70] & $\begin{array}{l}\text { Zhou Y, Groote R, } \\
\text { Goossens JGP, Sijbesma } \\
\text { RP, Heuts JPA. }\end{array}$ & $\begin{array}{l}\text { Tuning PBT vitrimer properties } \\
\text { by controlling the dynamics of } \\
\text { the adaptable network. }\end{array}$ & Polym Chem & 2019 & ;10:136-44. \\
\hline [71] & $\begin{array}{l}\text { Liu W, Schmidt DF, } \\
\text { Reynaud E. }\end{array}$ & $\begin{array}{l}\text { Catalyst Selection, Creep, and } \\
\text { Stress Relaxation in High- } \\
\text { Performance Epoxy Vitrimers. }\end{array}$ & Ind Eng Chem Res & 2017 & ;56:2667-72. \\
\hline [72] & $\begin{array}{l}\text { Snyder RL, Fortman DJ, } \\
\text { De Hoe GX, Hillmyer MA, } \\
\text { Dichtel WR. }\end{array}$ & $\begin{array}{l}\text { Reprocessable Acid-Degradable } \\
\text { Polycarbonate Vitrimers. }\end{array}$ & Macromolecules & 2018 & ;51:389-97. \\
\hline [73] & $\begin{array}{l}\text { Stukenbroeker T, Wang } \\
\text { W, Winne JM, Du Prez FE, } \\
\text { Nicolaÿ R, Leibler L. }\end{array}$ & $\begin{array}{l}\text { Polydimethylsiloxane } \\
\text { quenchable vitrimers. }\end{array}$ & Polym Chem & 2017 & ;8:6590-3. \\
\hline [74] & $\begin{array}{l}\text { Cromwell OR, Chung J, } \\
\text { Guan Z. }\end{array}$ & $\begin{array}{l}\text { Malleable and Self-Healing } \\
\text { Covalent Polymer Networks } \\
\text { through Tunable Dynamic } \\
\text { Boronic Ester Bonds. }\end{array}$ & J Am Chem Soc & 2015 & ;137:6492-5. \\
\hline$[75]$ & $\begin{array}{l}\text { Pei Z, Yang Y, Chen Q, } \\
\text { Wei Y, Ji Y. }\end{array}$ & $\begin{array}{l}\text { Regional Shape Control of } \\
\text { Strategically Assembled } \\
\text { Multishape Memory Vitrimers. }\end{array}$ & Adv Mater & 2016 & ;28:156-60. \\
\hline [76] & Lu YX, Guan Z. & $\begin{array}{l}\text { Olefin metathesis for effective } \\
\text { polymer healing via dynamic } \\
\text { exchange of strong carbon- } \\
\text { carbon double bonds. }\end{array}$ & J Am Chem Soc & 2012 & ;134:14226-31. \\
\hline [77] & $\begin{array}{l}\text { Chabert E, Vial J, Cauchois } \\
\text { JP, Mihaluta M, } \\
\text { Tournilhac F. }\end{array}$ & $\begin{array}{l}\text { Multiple welding of long fiber } \\
\text { epoxy vitrimer composites. }\end{array}$ & Soft Matter & 2016 & ;12:4838-45. \\
\hline [78] & $\begin{array}{l}\text { Taynton P, Ni H, Zhu C, Yu } \\
\text { K, Loob S, Jin Y, et al. }\end{array}$ & $\begin{array}{l}\text { Repairable Woven Carbon Fiber } \\
\text { Composites with Full } \\
\text { Recyclability Enabled by } \\
\text { Malleable Polyimine Networks. }\end{array}$ & Adv Mater & 2016 & ;28:2904-9. \\
\hline [79] & $\begin{array}{l}\text { Solouki Bonab V, } \\
\text { Karimkhani V, Manas- } \\
\text { Zloczower I. }\end{array}$ & $\begin{array}{l}\text { Ultra-Fast Microwave Assisted } \\
\text { Self-Healing of Covalent } \\
\text { Adaptive Polyurethane } \\
\text { Networks with Carbon } \\
\text { Nanotubes. }\end{array}$ & $\begin{array}{l}\text { Macromol Chem } \\
\text { Eng }\end{array}$ & 2019 & ;304:1800405/1-7. \\
\hline$[80]$ & $\begin{array}{l}\text { Yang Y, Pei Z, Zhang X, } \\
\text { Tao L, Wei Y, Ji Y. }\end{array}$ & $\begin{array}{l}\text { Carbon nanotube-vitrimer } \\
\text { composite for facile and } \\
\text { efficient photo-welding of } \\
\text { epoxy. }\end{array}$ & Chem Sci & 2014 & ;5:3486-92. \\
\hline [81] & Wang Z, Li Z, Wei Y, Ji Y. & $\begin{array}{l}\text { Gold Nanospheres Dispersed } \\
\text { Light Responsive Epoxy } \\
\text { Vitrimers. }\end{array}$ & Polymers & 2018 & ;10:65/1-7. \\
\hline [82] & $\begin{array}{l}\text { Li Z, Yang Y, Wang Z, } \\
\text { Zhang X, Chen Q, Qian X, } \\
\text { et al. }\end{array}$ & $\begin{array}{l}\text { Polydopamine nanoparticles } \\
\text { doped in liquid crystal } \\
\text { elastomers for producing } \\
\text { dynamic 3D structures. }\end{array}$ & J Mater Chem A & 2017 & ;5:6740-6. \\
\hline [83] & $\begin{array}{l}\text { Kasemsiri P, } \\
\text { Lorwanishpaisarn N, } \\
\text { Pongsa U, Ando S. }\end{array}$ & $\begin{array}{l}\text { Reconfigurable Shape Memory } \\
\text { and Self-Welding Properties of } \\
\text { Epoxy Phenolic } \\
\text { Novolac/Cashew Nut Shell } \\
\text { Liquid Composites Reinforced } \\
\text { with Carbon Nanotubes. }\end{array}$ & Polymers & 2018 & ;10:482/1-16. \\
\hline [84] & $\begin{array}{l}\text { Legrand A, Soulie-Ziakovic } \\
\text { C. }\end{array}$ & $\begin{array}{l}\text { Silica-Epoxy Vitrimer } \\
\text { Nanocomposites. }\end{array}$ & Macromolecules & 2016 & ;49:5893-902. \\
\hline
\end{tabular}




\begin{tabular}{|c|c|c|c|c|c|}
\hline [85] & $\begin{array}{l}\text { Huang Z, Wang Y, Zhu J, } \\
\text { Yu J, Hu Z. }\end{array}$ & $\begin{array}{l}\text { Surface engineering of } \\
\text { nanosilica for vitrimer } \\
\text { composites. }\end{array}$ & Compos Sci Technol & 2018 & ;154:18-27. \\
\hline [86] & $\begin{array}{l}\text { Li L, Chen X, Jin K, } \\
\text { Torkelson JM. }\end{array}$ & $\begin{array}{l}\text { Vitrimers Designed Both To } \\
\text { Strongly Suppress Creep and To } \\
\text { Recover Original Cross-Link } \\
\text { Density after Reprocessing: } \\
\text { Quantitative Theory and } \\
\text { Experiments. }\end{array}$ & Macromolecules & 2018 & ;51:5537-46. \\
\hline [87] & $\begin{array}{l}\text { Breuillac A, Kassalias A, } \\
\text { Nicolaÿ R. }\end{array}$ & $\begin{array}{l}\text { Polybutadiene Vitrimers Based } \\
\text { on Dioxaborolane Chemistry } \\
\text { and Dual Networks with Static } \\
\text { and Dynamic Cross-links. }\end{array}$ & Macromolecules & 2019 & ;52:7102-13. \\
\hline [88] & $\begin{array}{l}\text { Yu K, Shi Q, Dunn ML, } \\
\text { Wang T, Qi HJ. }\end{array}$ & $\begin{array}{l}\text { Carbon Fiber Reinforced } \\
\text { Thermoset Composite with } \\
\text { Near } 100 \% \text { Recyclability. } \\
\end{array}$ & Adv Funct Mater & 2016 & ;26:6098-106. \\
\hline [89] & $\begin{array}{l}\text { Denissen W, De Baere I, } \\
\text { Van Paepegem W, Leibler } \\
\text { L, Winne J, Du Prez FE. }\end{array}$ & $\begin{array}{l}\text { Vinylogous Urea Vitrimers and } \\
\text { Their Application in Fiber } \\
\text { Reinforced Composites. }\end{array}$ & Macromolecules & 2018 & ;51:2054-64. \\
\hline [90] & $\begin{array}{l}\text { Dhers S, Vantomme G, } \\
\text { Averous L. }\end{array}$ & $\begin{array}{l}\text { A fully bio-based polyimine } \\
\text { vitrimer derived from fructose. }\end{array}$ & Green Chem & 2019 & ;21:1596-601. \\
\hline [91] & $\begin{array}{l}\text { Scott TF, Schneider AD, } \\
\text { Cook WD, Bowman CN. }\end{array}$ & $\begin{array}{l}\text { Photoinduced Plasticity in } \\
\text { Cross-Linked Polymers. }\end{array}$ & Science & 2005 & ;308:1615-7. \\
\hline [92] & $\begin{array}{l}\text { Rekondo A, Martin R, Ruiz } \\
\text { de Luzuriaga A, Cabanero } \\
\text { G, Grande HJ, Odriozola I. }\end{array}$ & $\begin{array}{l}\text { Catalyst-free room- } \\
\text { temperature self-healing } \\
\text { elastomers based on aromatic } \\
\text { disulfide metathesis. }\end{array}$ & Mater Horiz & 2014 & ;1:237-240. \\
\hline [93] & $\begin{array}{l}\text { Nicolaÿ R, Kamada J, Van } \\
\text { Wassen A, Matyjaszewski } \\
\text { K. }\end{array}$ & $\begin{array}{l}\text { Responsive Gels Based on a } \\
\text { Dynamic Covalent } \\
\text { Trithiocarbonate Cross-Linker. }\end{array}$ & Macromolecules & 2010 & ;43:4355-61. \\
\hline [94] & $\begin{array}{l}\text { Demongeot A, Groote R, } \\
\text { Goossens H, Hoeks T, } \\
\text { Tournilhac F, Leibler L. }\end{array}$ & $\begin{array}{l}\text { Cross-Linking of Poly(butylene } \\
\text { terephthalate) by Reactive } \\
\text { Extrusion Using Zn(II) Epoxy- } \\
\text { Vitrimer Chemistry. }\end{array}$ & Macromolecules & 2017 & ;50:6117-27. \\
\hline [95] & $\begin{array}{l}\text { Zhou Y, Goossens JGP, } \\
\text { Sijbesma RP, Heuts JPA. }\end{array}$ & $\begin{array}{l}\text { Poly(butylene } \\
\text { terephthalate)/Glycerol-based } \\
\text { Vitrimers via Solid-State } \\
\text { Polymerization. }\end{array}$ & Macromolecules & 2017 & ;50:6742-51. \\
\hline [96] & $\begin{array}{l}\text { Lu YX, Tournilhac F, } \\
\text { Leibler L, Guan Z. }\end{array}$ & $\begin{array}{l}\text { Making Insoluble Polymer } \\
\text { Networks Malleable via Olefin } \\
\text { Metathesis. }\end{array}$ & J Am Chem Soc & 2012 & ;134:8424-7. \\
\hline [97] & Ishibashi JSA, Kalow JA. & $\begin{array}{l}\text { Vitrimeric Silicone Elastomers } \\
\text { Enabled by Dynamic Meldrum's } \\
\text { Acid-Derived Cross-Links. }\end{array}$ & ACS Macro Lett & 2018 & ;7:482-6. \\
\hline [98] & $\begin{array}{l}\text { Lessard JJ, Garcia LF, } \\
\text { Easterling CP, Sims MB, } \\
\text { Bentz KC, Arencibia S, et } \\
\text { al. }\end{array}$ & $\begin{array}{l}\text { Catalyst-Free Vitrimers from } \\
\text { Vinyl Polymers. }\end{array}$ & Macromolecules & 2019 & ;52:2105-11. \\
\hline [99] & Caffy F, Nicolaÿ R. & $\begin{array}{l}\text { Transformation of polyethylene } \\
\text { into a vitrimer by nitroxide } \\
\text { radical coupling of a bis- } \\
\text { dioxaborolane. }\end{array}$ & Polym Chem & 2019 & ;10:3107-15. \\
\hline [100] & $\begin{array}{l}\text { Kloxin CJ, Scott TF, } \\
\text { Adzima BJ, Bowman CN. }\end{array}$ & $\begin{array}{l}\text { Covalent Adaptable Networks } \\
\text { (CANs): A Unique Paradigm in } \\
\text { Crosslinked Polymers. }\end{array}$ & Macromolecules & 2010 & ;43:2643-53. \\
\hline
\end{tabular}




\begin{tabular}{|c|c|c|c|c|c|}
\hline [101] & Imbernon L, Norvez S. & $\begin{array}{l}\text { From landfilling to vitrimer } \\
\text { chemistry in rubber life cycle. }\end{array}$ & Eur Polym J & 2016 & ;82:347-76. \\
\hline [102] & $\begin{array}{l}\text { Urdl K, Kandelbauer A, } \\
\text { Kern W, Müller U, } \\
\text { Thebault M, Zikulnig- } \\
\text { Rusch E. }\end{array}$ & $\begin{array}{l}\text { Self-healing of densely } \\
\text { crosslinked thermoset } \\
\text { polymers-a critical review. }\end{array}$ & Prog Org Coat & 2017 & ;104:232-49. \\
\hline [103] & $\begin{array}{l}\text { Zou W, Dong J, Luo Y, } \\
\text { Zhao Q, Xie T. }\end{array}$ & $\begin{array}{l}\text { Dynamic Covalent Polymer } \\
\text { Networks: from Old Chemistry } \\
\text { to Modern Day Innovations. }\end{array}$ & Adv Mater & 2017 & ;29:1606100/1-18. \\
\hline [104] & $\begin{array}{l}\text { Fortman DJ, Brutman JP, } \\
\text { De Hoe GX, Snyder RL, } \\
\text { Dichtel WR, Hillmyer MA. }\end{array}$ & $\begin{array}{l}\text { Approaches to Sustainable and } \\
\text { Continually Recyclable Cross- } \\
\text { Linked Polymers. }\end{array}$ & $\begin{array}{l}\text { ACS Sustain Chem } \\
\text { Eng }\end{array}$ & 2018 & ;6:11145-59. \\
\hline [105] & $\begin{array}{l}\text { Scheutz GM, Lessard JJ, } \\
\text { Sims MB, Sumerlin BS. }\end{array}$ & $\begin{array}{l}\text { Adaptable Crosslinks in } \\
\text { Polymeric Materials: Resolving } \\
\text { the Intersection of } \\
\text { Thermoplastics and } \\
\text { Thermosets. }\end{array}$ & J Am Chem Soc & 2019 & ;141:16181-96. \\
\hline [106] & $\begin{array}{l}\text { Winne JM, Leibler L, Du } \\
\text { Prez FE. }\end{array}$ & $\begin{array}{l}\text { Dynamic covalent chemistry in } \\
\text { polymer networks: a } \\
\text { mechanistic perspective. }\end{array}$ & Polym Chem & 2019 & ;10:6091-108. \\
\hline [107] & $\begin{array}{l}\text { Zhou Y, Goossens JGP, } \\
\text { van den Bergen S, } \\
\text { Sijbesma RP, Heuts JPA. }\end{array}$ & $\begin{array}{l}\text { In Situ Network Formation in } \\
\text { PBT Vitrimers via Processing- } \\
\text { Induced Deprotection } \\
\text { Chemistry. }\end{array}$ & $\begin{array}{l}\text { Macromol Rapid } \\
\text { Comm }\end{array}$ & 2018 & ;39:1800356/1-7. \\
\hline [108] & $\begin{array}{l}\text { Yan P, Zhao W, Fu X, Liu } \\
\text { Z, Kong W, Zhou C, et al. }\end{array}$ & $\begin{array}{l}\text { Multifunctional polyurethane- } \\
\text { vitrimers completely based on } \\
\text { transcarbamoylation of } \\
\text { carbamates: thermally-induced } \\
\text { dual-shape memory effect and } \\
\text { self-welding. }\end{array}$ & RSC Adv & 2017 & ;7:26858-66. \\
\hline [109] & $\begin{array}{l}\text { Kuhl N, Abend M, Geitner } \\
\text { R, Vitz J, Zechel S, Schmitt } \\
\text { M, et al. }\end{array}$ & $\begin{array}{l}\text { Urethanes as reversible } \\
\text { covalent moieties in self- } \\
\text { healing polymers. }\end{array}$ & Eur Polym J & 2018 & ;104:45-50. \\
\hline [110] & Zhang L, Rowan SJ. & $\begin{array}{l}\text { Effect of Sterics and Degree of } \\
\text { Cross-Linking on the } \\
\text { Mechanical Properties of } \\
\text { Dynamic Poly(alkylurea- } \\
\text { urethane) Networks. }\end{array}$ & Macromolecules & 2017 & ;50:5051-60. \\
\hline [111] & $\begin{array}{l}\text { Erice A, Ruiz de Luzuriaga } \\
\text { A, Matxain JM, Ruipérez } \\
\text { F, Asua JM, Grande HJ, et } \\
\text { al. }\end{array}$ & $\begin{array}{l}\text { Reprocessable and recyclable } \\
\text { crosslinked poly(urea- } \\
\text { urethane)s based on dynamic } \\
\text { amine/urea exchange. }\end{array}$ & Polymer & 2018 & ;145:127-36. \\
\hline [112] & $\begin{array}{l}\text { Christensen PR, } \\
\text { Scheuermann AM, } \\
\text { Loeffler KE, Helms BA. }\end{array}$ & $\begin{array}{l}\text { Closed-loop recycling of plastics } \\
\text { enabled by dynamic covalent } \\
\text { diketoenamine bonds. }\end{array}$ & Nat Chem & 2019 & ;11:442-8. \\
\hline [113] & Zhao S, Abu-Omar MM. & $\begin{array}{l}\text { Recyclable and Malleable Epoxy } \\
\text { Thermoset Bearing Aromatic } \\
\text { Imine Bonds. }\end{array}$ & Macromolecules & 2018 & ;51:9816-24. \\
\hline [114] & $\begin{array}{l}\text { Zheng } \mathrm{H} \text {, Liu Q, Lei X, } \\
\text { Chen } \mathrm{Y} \text {, Zhang B, Zhang Q. }\end{array}$ & $\begin{array}{l}\text { A conjugation polyimine } \\
\text { vitrimer: Fabrication and } \\
\text { performance. }\end{array}$ & $\begin{array}{l}\text { J Polym Sci Part A } \\
\text { Polym Chem }\end{array}$ & 2018 & ;56:2531-8. \\
\hline [115] & $\begin{array}{l}\text { Pepels M, Filot I, } \\
\text { Klumperman B, Goossens } \\
\text { H. }\end{array}$ & $\begin{array}{l}\text { Self-healing systems based on } \\
\text { disulfide-thiol exchange } \\
\text { reactions. }\end{array}$ & Polym Chem & 2013 & ;4:4955-65. \\
\hline [116] & $\begin{array}{l}\text { Cash JJ, Kubo T, Dobbins } \\
\text { DJ, Sumerlin BS. }\end{array}$ & $\begin{array}{l}\text { Maximizing the symbiosis of } \\
\text { static and dynamic bonds in } \\
\text { self-healing boronic ester }\end{array}$ & Polym Chem & 2018 & ;9:2011-20. \\
\hline
\end{tabular}




\begin{tabular}{|c|c|c|c|c|c|}
\hline & & networks. & & & \\
\hline [117] & $\begin{array}{l}\text { Bao C, Jiang YJ, Zhang H, } \\
\text { Lu X, Sun J. }\end{array}$ & $\begin{array}{l}\text { Room-Temperature Self- } \\
\text { Healing and Recyclable Tough } \\
\text { Polymer Composites Using } \\
\text { Nitrogen-Coordinated } \\
\text { Boroxines. }\end{array}$ & Adv Funct Mater & 2018 & ;28:1800560/1-10. \\
\hline [118] & $\begin{array}{l}\text { Wu X, Yang X, Yu R, Zhao } \\
\text { XJ, Zhang Y, Huang W. }\end{array}$ & $\begin{array}{l}\text { A facile access to stiff epoxy } \\
\text { vitrimers with excellent } \\
\text { mechanical properties via } \\
\text { siloxane equilibration. }\end{array}$ & J Mater Chem A & 2018 & ;6:10184-8. \\
\hline [119] & Zheng P, McCarthy TJ. & $\begin{array}{l}\text { A surprise from 1954: siloxane } \\
\text { equilibration is a simple, } \\
\text { robust, and obvious polymer } \\
\text { self-healing mechanism. }\end{array}$ & J Am Chem Soc & 2012 & ;134:2024-7. \\
\hline [120] & $\begin{array}{l}\text { Han J, Liu T, Hao C, Zhang } \\
\text { S, Guo B, Zhang J. }\end{array}$ & $\begin{array}{l}\text { A Catalyst-Free Epoxy Vitrimer } \\
\text { System Based on } \\
\text { Multifunctional Hyperbranched } \\
\text { Polymer. }\end{array}$ & Macromolecules & 2018 & ;51:6789-99. \\
\hline [121] & $\begin{array}{l}\text { Tellers J, Pinalli R, } \\
\text { Soliman M, Vachon J, } \\
\text { Dalcanale E. }\end{array}$ & $\begin{array}{l}\text { Reprocessable vinylogous } \\
\text { urethane cross-linked } \\
\text { polyethylene via reactive } \\
\text { extrusion. }\end{array}$ & Polym Chem & 2019 & ;10:5534-42. \\
\hline [122] & $\begin{array}{l}\text { Demongeot A, Groote R, } \\
\text { Goossens H, Hoeks T, } \\
\text { Tournilhac F, Leibler L. }\end{array}$ & $\begin{array}{l}\text { Cross-Linking of Poly(butylene } \\
\text { terephthalate) by Reactive } \\
\text { Extrusion Using Zn(II) Epoxy- } \\
\text { Vitrimer Chemistry. }\end{array}$ & Macromolecules & 2017 & ;50:6117-27. \\
\hline [123] & $\begin{array}{l}\text { Leibler L, Rubinstein M, } \\
\text { Colby RH. }\end{array}$ & $\begin{array}{l}\text { Dynamics of reversible } \\
\text { networks. }\end{array}$ & Macromolecules & 1991 & ;24:4701-7. \\
\hline [124] & $\begin{array}{l}\text { Rubinstein M, Semenov } \\
\text { AN. }\end{array}$ & $\begin{array}{l}\text { Thermoreversible gelation in } \\
\text { solutions of associating } \\
\text { polymers: } 2 \text {. Linear dynamics. }\end{array}$ & Macromolecules & 1998 & ;31:1386-97. \\
\hline [125] & $\begin{array}{l}\text { Rubinstein M, Semenov } \\
\text { AN. }\end{array}$ & $\begin{array}{l}\text { Dynamics of Entangled } \\
\text { Solutions of Associating } \\
\text { Polymers. }\end{array}$ & Macromolecules & 2001 & ;34:1058-68. \\
\hline [126] & $\begin{array}{l}\text { Yang Y, Zhang S, Zhang X, } \\
\text { Gao L, Wei Y, Ji Y. }\end{array}$ & $\begin{array}{l}\text { Detecting topology freezing } \\
\text { transition temperature of } \\
\text { vitrimers by AIE luminogens. }\end{array}$ & Nat Commun & 2019 & ;10:3165/1-8. \\
\hline [127] & $\begin{array}{l}\text { Wen Z, McBride MK, } \\
\text { Zhang X, Han X, Martinez } \\
\text { AM, Shao R, et al. }\end{array}$ & $\begin{array}{l}\text { Reconfigurable LC Elastomers: } \\
\text { Using a Thermally } \\
\text { Programmable Monodomain } \\
\text { To Access Two-Way Free- } \\
\text { Standing Multiple Shape } \\
\text { Memory Polymers. }\end{array}$ & Macromolecules & 2018 & ;51:5812-9. \\
\hline [128] & $\begin{array}{l}\text { Pei Z, Yang Y, Chen Q, } \\
\text { Terentjev EM, Wei Y, Ji Y. }\end{array}$ & $\begin{array}{l}\text { Mouldable liquid-crystalline } \\
\text { elastomer actuators with } \\
\text { exchangeable covalent bonds. }\end{array}$ & Nat Mater & 2014 & ;13:36-41. \\
\hline [129] & $\begin{array}{l}\text { Chen Y, Tang Z, Liu Y, Wu } \\
\text { S, Guo B. }\end{array}$ & $\begin{array}{l}\text { Mechanically Robust, Self- } \\
\text { Healable, and Reprocessable } \\
\text { Elastomers Enabled by Dynamic } \\
\text { Dual Cross-Links. }\end{array}$ & Macromolecules & 2019 & ;52:3805-12. \\
\hline [130] & $\begin{array}{l}\text { Niu X, Wang F, Kui X, } \\
\text { Zhang R, Wang X, Li X, et } \\
\text { al. }\end{array}$ & $\begin{array}{l}\text { Dual Cross-linked Vinyl Vitrimer } \\
\text { with Efficient Self-Catalysis } \\
\text { Achieving Triple-Shape- } \\
\text { Memory Properties. }\end{array}$ & $\begin{array}{l}\text { Macromol Rapid } \\
\text { Commun }\end{array}$ & 2019 & ;40:1900313/1-8. \\
\hline
\end{tabular}




\begin{tabular}{|c|c|c|c|c|c|}
\hline [131] & $\begin{array}{l}\text { Ricarte RG, Tournilhac F, } \\
\text { Leibler L. }\end{array}$ & $\begin{array}{l}\text { Phase Separation and Self- } \\
\text { Assembly in Vitrimers: } \\
\text { Hierarchical Morphology of } \\
\text { Molten and Semicrystalline } \\
\text { Polyethylene/Dioxaborolane } \\
\text { Maleimide Systems. }\end{array}$ & Macromolecules & 2019 & ;52:432-43. \\
\hline [132] & $\begin{array}{l}\text { Lessard JJ, Scheutz GM, } \\
\text { Sung SH, Lantz KA, Epps } \\
\text { TH, 3rd, Sumerlin BS. } \\
\end{array}$ & Block Copolymer Vitrimers. & J Am Chem Soc & 2020 & ;142:283-9. \\
\hline [133] & $\begin{array}{l}\text { DiCiccio AM, Lee YL, } \\
\text { Glettig DL, Walton ESE, de } \\
\text { la Serna EL, Montgomery } \\
\text { VA, et al. }\end{array}$ & Caffeine-catalyzed gels. & Biomaterials & 2018 & ;170:127-35. \\
\hline [134] & $\begin{array}{l}\text { Shi Q, Yu K, Kuang X, Mu } \\
\text { X, Dunn CK, Dunn ML, et } \\
\text { al. }\end{array}$ & $\begin{array}{l}\text { Recyclable 3D printing of } \\
\text { vitrimer epoxy. }\end{array}$ & Mater Horiz & 2017 & ;4:598-607. \\
\hline [135] & $\begin{array}{l}\text { Zhang B, Kowsari K, } \\
\text { Serjouei A, Dunn ML, Ge } \\
\text { Q. }\end{array}$ & $\begin{array}{l}\text { Reprocessable thermosets for } \\
\text { sustainable three-dimensional } \\
\text { printing. }\end{array}$ & Nat Commun & 2018 & ;9:1831/1-7. \\
\hline [136] & $\begin{array}{l}\text { Lyon GB, Cox LM, } \\
\text { Goodrich JT, Baranek AD, } \\
\text { Ding Y, Bowman CN. }\end{array}$ & $\begin{array}{l}\text { Remoldable Thiol-Ene } \\
\text { Vitrimers for Photopatterning } \\
\text { and Nanoimprint Lithography. }\end{array}$ & Macromolecules & 2016 & ;49:8905-13. \\
\hline
\end{tabular}

